Open Access

\title{
Differential bioreactivity of neutral, cationic and anionic polystyrene nanoparticles with cells from the human alveolar compartment: robust response of alveolar type 1 epithelial cells
}

\author{
Pakatip Ruenraroengsak and Teresa D. Tetley ${ }^{*}$
}

\begin{abstract}
Background: Engineered nanoparticles (NP) are being developed for inhaled drug delivery. This route is non-invasive and the major target; alveolar epithelium provides a large surface area for drug administration and absorption, without first pass metabolism. Understanding the interaction between NPs and target cells is crucial for safe and effective NP-based drug delivery. We explored the differential effect of neutral, cationic and anionic polystyrene latex NPs on the target cells of the human alveolus, using primary human alveolar macrophages (MAC) and primary human alveolar type 2 (AT2) epithelial cells and a unique human alveolar epithelial type I-like cell (TT1). We hypothesized that the bioreactivity of the NPs would relate to their surface chemistry, charge and size as well as the functional role of their interacting cells in vivo.

Methods: Amine- (ANP) and carboxyl- surface modified (CNP) and unmodified (UNP) polystyrene NPs, 50 and $100 \mathrm{~nm}$ in diameter, were studied. Cells were exposed to $1-100 \mu \mathrm{g} / \mathrm{ml}\left(1.25-125 \mu \mathrm{g} / \mathrm{cm}^{2} ; 0 \mu \mathrm{g} / \mathrm{ml}\right.$ control) NP for 4 and $24 \mathrm{~h}$ at $37^{\circ} \mathrm{C}$ with or without the antioxidant, $\mathrm{N}$-acetyl cysteine (NAC). Cells were assessed for cell viability, reactive oxygen species (ROS), oxidised glutathione (GSSG/GSH ratio), mitochondrial integrity, cell morphology and particle uptake (using electron microscopy and laser scanning confocal microscopy).

Results: ANP-induced cell death occurred in all cell types, inducing increased oxidative stress, mitochondrial disruption and release of cytochrome C, indicating apoptotic cell death. UNP and CNP exhibited little cytotoxicity or mitochondrial damage, although they induced ROS in AT2 and MACs. Addition of NAC reduced epithelial cell ROS, but not MAC ROS, for up to $4 \mathrm{~h}$. TT1 and MAC cells internalised all NP formats, whereas only a small fraction of AT2 cells internalized ANP (not UNP or CNP). TT1 cells were the most resistant to the effects of UNP and CNP.

Conclusion: ANP induced marked oxidative damage and cell death via apoptosis in all cell types, while UNP and CNP exhibited low cytotoxicity via oxidative stress. MAC and $T 1$ cell models show strong particle-internalization compared to the AT2 cell model, reflecting their cell function in vivo. The $50 \mathrm{~nm}$ NPs induced a higher bioreactivity in epithelial cells, whereas the $100 \mathrm{~nm}$ NPs show a stronger effect on phagocytic cells.
\end{abstract}

Keywords: Polystyrene nanoparticles, Amine-modified nanoparticles, Mitochondria, Oxidative stress, Surface modification, Human alveolar epithelial cells, Alveolar macrophages

\footnotetext{
* Correspondence: t.tetley@imperial.ac.uk

Lung Cell Biology, Section of Airways Disease, National Heart \& Lung

Institute, Imperial College London, Dovehouse Street, London SW3 6LY, UK
} 


\section{Background}

The emergence of nanotechnology and nanomedicine is of increasing interest, particularly for local and systemic treatment via inhaled drug delivery to the lung [1-4]; a range of NP-based agents have been developed to improve therapeutic and diagnostic efficiency, and to minimize adverse effects [5-8]. These products have been studied in vivo [9-11], and also in clinical trials and some have reached the clinic for the treatment of cancer, diabetes, and other lung diseases [6, 8, 12, 13] with varying degrees of success, related to a range of factors, including the unique physicochemical structure of each type of NP and its bioreactivity. Administration of drugs via the lung can be performed non-invasively offering several advantages: the thin alveolar epithelialendothelial barrier provides a large surface area with extensive vascularisation for effective drug absorption, low endogenous biotransformation activity and the drug will escape first pass metabolism in the liver [2, 3, 14]. Despite the increased use of inhalation of NPs for drug delivery [3, 15], little is known of the impact of engineered NPs on the alveolar epithelial barrier [7, 16]. It is suggested that deposition of both anthropogenic and engineered nano-sized particles could cause lung inflammation via oxidative stress, relating to their physicochemical properties $[17,18]$.

The alveolar respiratory unit is composed of alveolar type I (AT1) and type II (AT2) epithelial cells and alveolar macrophages (MAC). AT1 cells share a fused basement membrane with capillary endothelium to form a thin wall at the gas-blood barrier that facilitates gas exchange. AT2 cells secrete a range of molecules involved in lung defence and homeostasis, including lung surfactant which maintains reduced surface tension to prevent alveolar collapse; AT2 cells also proliferate and differentiate into AT1 cells to replace injured AT1 cells and have recently been described as an alveolar epithelial stem cell [19]. Alveolar macrophages (MAC) are responsible for removing foreign particles and other debris from the alveoli including allergens, microorganisms and inorganic particulate matter. All three cell types release proinflammatory mediators and we have demonstrated that interplay between these cells plays a vital role in regulating the pulmonary immune response [20, 21].

Regarding efficacious use of inhaled nano-drugs, the drug must be delivered intracellularly, involving NP uptake into and possibly translocation across the cell. For others, appropriate reactivity and delivery at the cell surface membrane is the aim $[9,22,23]$. However, it is important to appreciate the exact cellular responses, to avoid unwanted effects such as cytotoxicity, inflammation and tissue injury and therefore to optimise treatment. We hypothesised that NP size and surface modification would crucially impact on these processes, and the induction of oxidative stress would be a biomarker of unwanted effects of nano-drugs. Therefore in this novel study, we have examined the effect of nanosize and surface chemistry/charge of model polystyrene latex NPs on oxidative stress and cellular toxicity with immortalised human AT1 (TT1), primary human AT2 and MAC cells, representing the first cellular targets of inhaled nano-drugs in the human respiratory unit.

There is no standard in vitro model of the alveolar epithelial barrier to study drug transport, pharmacokinetics and bioreactivity; for example many in vitro studies utilise the A549 adenocarcinoma cell line as a substitute for primary human alveolar epithelial type II cells [24-26], whilst others utilise the Calu-3 human bronchial epithelial cell line, also derived from a pulmonary adenocarcinoma, to investigate changes in barrier function of large airway epithelium $[27,28]$. We believe it is also relevant to use cell lines derived from normal lung cells and primary cells [21]. Furthermore, it is not possible to isolate sufficient primary human alveolar type 1 epithelial cells (many of which do not survive the procedure), and there is no commercially available source, thus, we have generated a unique immortal human AT1-like cell line (TT1) [29] from their progenitor cells, primary human AT2 cells [30]. In parallel, we study freshly prepared human lung AT2 cells [30] and MACs, from the same pieces of human lung tissue with normal appearance, removed during surgery for lung cancer. We have used these models in the following studies of the interaction of 50 and $100 \mathrm{~nm}$ polystyrene latex NPs, unmodified (UNP) and also surface-modified with amine (ANP) and carboxyl groups (CNP).

\section{Results}

\section{Assessment of particle size and surface charge of latex nanoparticles}

The interaction of nanosized-materials with body fluids is an early event; we and others have shown that components of extracellular fluids adsorb to the particles [31-33]. Importantly, we recently showed that polystyrene latex nanoparticles adsorb components of the tissue culture medium [31], which is likely to alter the surface charge and format of the NPs presented to the cells. Here the hydrodynamic diameter and surface charge density of each surface group (Table 1) in distilled water (DW) and in tissue culture medium (DCCM1 and RPMI) were measured. All NPs were monodisperse in DW but formed small agglomerates in DCCM1 and RPMI (Table 1), as indicated by the increase in average hydrodynamic diameters and polydispersity index values (PDI), likely reflecting adsorption of proteins and other components of the medium [31]. The surface charge densities (measured as zeta potential; Table 1) of the NPs also depended on the dispersing medium; the 
Table 1 Surface chemistry, hydrodynamic diameter, and surface charge density of unmodified- (UNP), carboxyl-modified (CNP) and amine-modified (ANP) latex nanoparticles in distilled water (DW) and tissue culture medium (DCCM1 and RPMI)

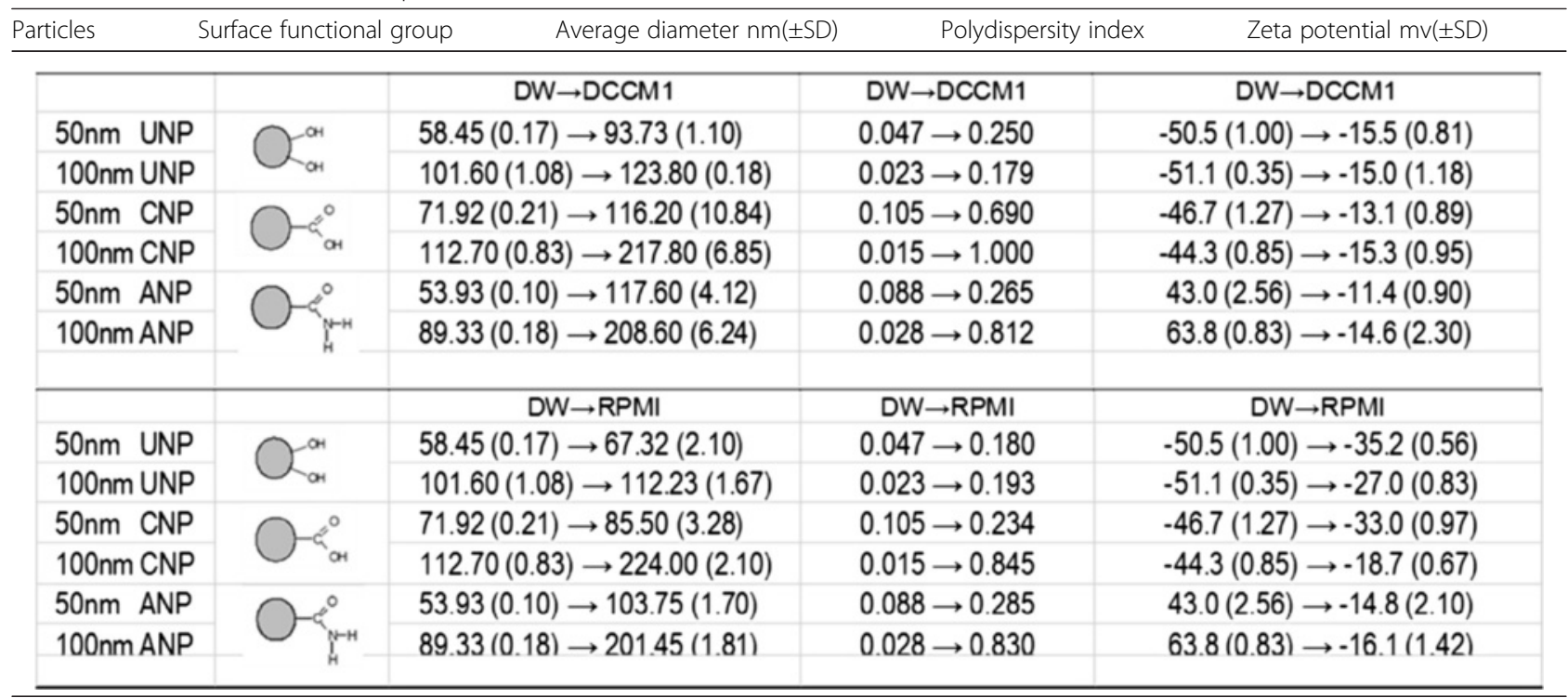

The data are presented as mean \pm standard deviation (SD), $n=3^{\beta}$

${ }^{\beta}$ Nanoparticles were suspended in distilled water and DCCM1 or RPMI at a concentration of $10 \mu \mathrm{g} / \mathrm{ml}$ and bath sonicated for 2 min before measurement (see methods)

$50 \mathrm{~nm}$ ANP $(+43.7 \pm 1 \mathrm{mV})$, CNP $(-46.7 \pm 1.27 \mathrm{mV})$ and UNP $(-50.5 \pm 2.56 \mathrm{mV})$ show strong positive and negative surface charge densities in DW relating to their surface functional group (-OH for UNP,-COOH for CNP and $-\mathrm{NH} 2$ for ANP; Table 1), but their surface charge became very similarly moderately negative, regardless of their original charge, in DCCM1, as follows: ANP $(-11.4 \pm 0.90 \mathrm{mV}), \mathrm{CNP}(-13.1 \pm 0.89 \mathrm{mV})$ and UNP $(-15.5 \pm 0.81 \mathrm{mV})$ and in RPMI ANP $(-35.2 \pm 0.56 \mathrm{mV})$, $\mathrm{CNP}(-33.0 \pm 0.97 \mathrm{mV})$ and UNP $(-14.8 \pm 2.10 \mathrm{mV})$.

\section{Effect of size and surface chemistry on cell viability}

Previously we reported that $50 \mathrm{~nm}$ ANP induced cell death and pore formation at the cell membrane of TT1 cells, together with increased release of IL-6 and IL-8 and activation of caspase $3 / 7$ and 9 [31]. Here, we further investigated the effect of NPs on their ability to induce intracellular reactive oxygen species (ROS) as this might impact on cell viability and bioreactivity. The $50 \mathrm{~nm}$ ANPs were reported to be more toxic than $100 \mathrm{~nm}$ ANPs; $50 \mathrm{~nm}$ ANPs were also more toxic than $50 \mathrm{~nm}$ UNPs and CNPs after $24 \mathrm{~h}$ exposure [31]. In this study, we showed that following $4 \mathrm{~h}$ exposure, there was only a slight toxic effect of ANP on TT1 at concentrations between $50-100 \mu \mathrm{g} / \mathrm{ml}$ (Additional file 1: Figure S1). We also investigated if the same response profile would occur with AT2 and MACs using a similar NP concentration range and 24 hour exposure. The cytotoxicity of 50 and $100 \mathrm{~nm}$ NPs against TT1, AT2 cells and MACs showed a similar pattern of response, where
ANPs, but not UNPs or CNPs, were very cytotoxic (Fig. 1a-f). The $50 \mathrm{~nm}$ ANPs were toxic even at the lower concentrations of 10 and $25 \mu \mathrm{g} / \mathrm{ml}(t=24 \mathrm{~h}$, $n=6$ ), inducing approximately $20 \%$ cell death, compared to $<10 \%$ cell death for the same concentrations of $50 \mathrm{~nm}$ UNP and CNP and $100 \mathrm{~nm}$ ANPs. ANPs, $50 \mu \mathrm{g} /$ $\mathrm{ml}$, induced approximately $50 \%$ cell death in MACs, compared to $30-35 \%$ cell death $(t=24 \mathrm{~h}, n=6)$ in the epithelial cells, although the highest concentration, $100 \mu \mathrm{g} / \mathrm{ml}$ ANP caused a similar degree of cell death in all cell types ( $\sim 60 \%$; Fig. $1 \mathrm{~b}, \mathrm{~d}$ and $\mathrm{f})$. At the highest concentration of $100 \mathrm{~nm}$ NPs there was approximately 45-50\% AT2 and MAC cell death (Fig. 1d and f), although TT1 cells exhibited less than $20 \%$ cell death at this concentration (Fig. 1b). We suspected that oxidative stress might associate with ANP toxicity, and therefore, the addition of antioxidant $\mathrm{N}$-acetyl-cysteine (NAC, $10 \mathrm{mM}$ ) would reduce cell death following ANP exposure. When TT1, AT2 cells and MACs were exposed to the $50 \mathrm{~nm}$ NPs $(t=24 \mathrm{~h})$ in the presence of NAC (Fig. 1gi, Additional file 1: Figure S2), there was little effect on the UNP- or CNP-treated cells, as expected due to little effect of the NPs alone (Additional file 1: Figure S2). Regarding the marked cell death induced by $50 \mathrm{~nm}$ ANP, there was no improvement in cell viability of TT1 cells (Fig. 1g). In MACs, NAC had only a small protective effect on cell death at $10 \mu \mathrm{g} / \mathrm{ml}$ ANP (Fig. 1i). However, in AT2 cells (Fig. 1h), NAC prevented the effects of 10 and $25 \mu \mathrm{g} / \mathrm{ml}$ $50 \mathrm{~nm}$ ANP, and caused a small improvement in the effect of $100 \mu \mathrm{g} / \mathrm{ml}$ ANP on AT2 cell viability. 


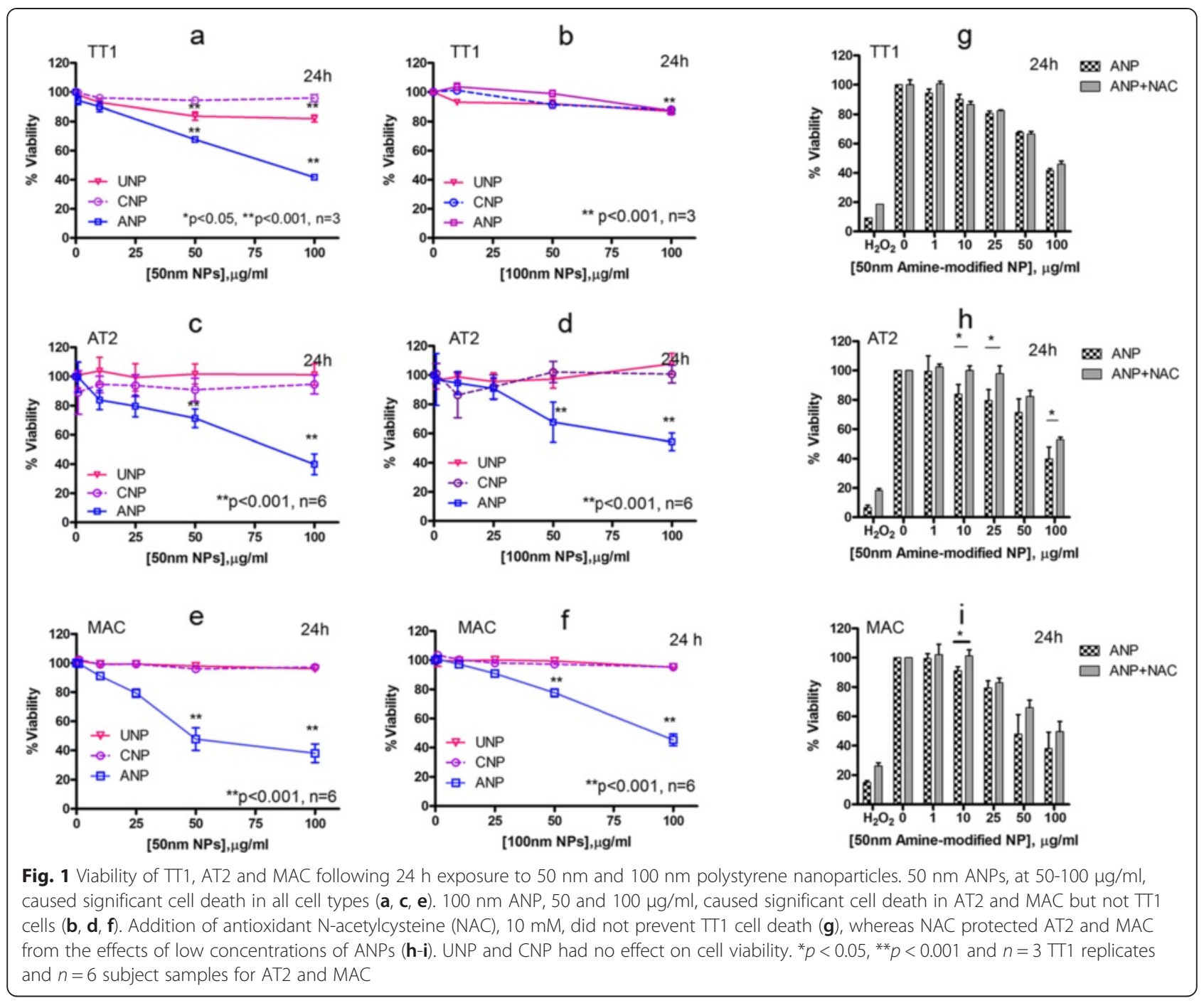

We also observed toxicity of NPs in all cell types using the lactate dehydrogenase (LDH) assay to examine membrane integrity $(n=6, t=4$ and $24 \mathrm{~h}$; Additional file 1: Figure S3-S4). We previously observed a marked release of LDH by TT1 cells exposed to $50 \mathrm{~nm}$ ANP (but not UNP or CNP) which paralleled the formation of "holes" within the cell membrane [31]. AT2 cells exposed to all types of 50 and $100 \mathrm{~nm}$ ANPs released LDH (Additional file 1: Figure S3); the most significant release of LDH was on exposure to $50 \mathrm{~nm}$ CNPs, ANPs and $100 \mathrm{~nm}$ ANPs $(p<0.001, n=6)$. The release of LDH was time and NP concentration dependent; the smaller NPs induced the highest $\mathrm{LDH}$. At the higher concentrations of $50 \mathrm{~nm}$ ANPs $(25-100 \mu \mathrm{g} / \mathrm{ml})$, there was up to $60 \%$ LHD release, which mirrored MTT estimation of AT2 cell death (Fig. 1c-d). In contrast, in the MAC studies, the $100 \mathrm{~nm}$ NPs had the greatest effect on LDH release compared to $50 \mathrm{~nm}$ NPs following $24 \mathrm{~h}$ exposure $(p<$ $0.001, n=6$; Additional file 1: Figure S4), which was also concentration and time dependent. ANPs exhibited higher toxicity than UNPs and CNPs, and there was marked release of LDH at the higher concentrations of $100 \mathrm{~nm}$ ANPs $(25-100 \mu \mathrm{g} / \mathrm{ml})$ causing up to $75 \% \mathrm{LDH}$ release following $24 \mathrm{~h}$ exposure, in parallel to the MTT measure of cell death (Fig. 1e and f). Interestingly, LDH did not exactly mirror MTT measure of cell death for MAC experiments exposed to $100 \mathrm{~nm}$ UNP and CNP.

\section{Effect of nanoparticles on the release of inflammatory mediators, IL-6 and IL-8}

Following $24 \mathrm{~h}$ exposure, all types of NPs activated significant increased release of IL-6 and IL- $8(p<0.001$, $n=6$ ) by AT2 cells and MAC (Additional file 1: Figure S5). The increase in IL- 6 release by AT2 was much the same regardless of NP concentration or surface modification. This may in part reflect the similarity in surface charge density (zeta potential) between the NPs, which was similar in DCCM1 medium, between -11.4 and $-15.5 \mathrm{mV}$ 
(Table 1), but does not address the lack of effect of increasing NP concentration. The marked increase at even low NP concentrations may be due to induction of the maximal IL- 6 response. Neither is it clear why there are no differences between the magnitude of the effect of 50 and $100 \mathrm{~nm}$ NPs, considering the marked increase in NP numbers and surface area/unit weight of the $50 \mathrm{~nm}$ NPs, as discussed previously [31]. In contrast, an effect of particle size was observed for release of IL-8 (Additional file 1: Figure S5d-f); $50 \mathrm{~nm}$ NPs induced a significantly greater release of IL-8 than that of the $100 \mathrm{~nm}$ NPs. However, as for IL-6, there was no effect of increasing NP concentration on AT2 cell IL-8 release. In contrast, for MACs (Additional file 1: Figure S6) increased release of IL-6 and IL-8 correlated with NP concentration. Surface chemistry was important $(p<0.001, n=6)$; ANPs and UNPs induced the greatest, similar levels of IL- 6 and IL- 8 release, compared to CNPs. Again, there was little effect of NP size on IL-6 release, whereas $100 \mathrm{~nm} \mathrm{UNP} \mathrm{and}$ CNP induced more IL- 8 release than did the $50 \mathrm{~nm}$ NPs. We previously reported that all three types of $50 \mathrm{~nm}$ NPs stimulated a concentration-dependent release of IL- 6 and IL- 8 by TT1 cells [31]. Others have shown that polystyrene latex stimulated IL-8 release by A549 cells; the smallest, $60 \mathrm{~nm}$ NPs, caused the highest release compared to 200 and $500 \mathrm{~nm}$ NPs [34]. Prietl et al. reported a similar pattern of IL- 8 release by macrophages exposed to 20,500 and $1000 \mathrm{~nm}$ carboxyl modified latex particles [35].

\section{Effect of nanoparticles on the activation of intracellular reactive oxygen species (ROS)}

We used 2', 7'-dichlorodihydrofluorescein diacetate (H2-DCFDA; to detect peroxide and singlet oxygen) and dihydroethidium (DHE; to detect superoxide radicals) dyes to monitor intracellular ROS. Both dyes indicated a similar pattern of ROS induction within TT1 cells; however, only DHE effectively detected ROS in AT2 and MAC, indicating differences in ROS production between the cells. ANPs $(50 \mathrm{~nm})$ significantly initiated ROS production in TT1 cells in a concentration dependent manner at $4 \mathrm{~h}$, when there was no cell death $(p<0.001$, $n=3$; Additional file 1: Figure S1, S7a-d, s). The ROS detected by H2-DCFDA remained over $24 \mathrm{~h}$, when there was significant cell death, as can be seen by cell loss in Additional file 1: Figure S7f. UNPs did not initiate ROS detected by H2-DCFDA in TT1, whereas CNPs took up to $24 \mathrm{~h}$ to induce ROS (Additional file 1: Figure S7). ANPs induced massive production of ROS (detected by DHE and H2-DCFDA) in TT1 cells, $p<0.001, n=3$, at both 4 and $24 \mathrm{~h}$ (Fig. 2d, aa. Additional file 1: Figure S7a-d, f, s-t). Although UNPs and CNPs induced TT1 ROS, it was much lower than that observed with ANP
(Fig. 2b and c, aa; Additional file 1: Figure S7g-h, t). In contrast, all types of NPs initiated significant production of ROS (detected by DHE) in AT2 $(p<0.001, n=3$, Fig. 2j, k, l and ab) and MACs (Fig. 2r, s, t and ac), which in AT2 cells was concentration-dependent (Additional file 1: Figure S7i-r, u). This effect was completely eliminated in AT2 cells by co-incubating the antioxidant $\mathrm{N}$ acetyl-cysteine (10 mM) with the NPs (Fig. 2n, o, p and $\mathrm{ab}$ ), which also prevented ROS formation in TT1 cells exposed to UNP and CNP (Fig. 2f- g, aa), though only partially eliminated ROS in TT1 cells exposed to ANP (Fig. 2h, aa). In contrast, NAC had little effect when added to NP-exposed MACs, regardless of surface modification (Fig. 2v-x, ac). Although the induction of oxidative stress was observed following NP exposure to all types of NPs, differences were observed in the magnitude and profile of ROS activity relating to both surface modification and cell type (Fig. 2aa, ab, ac). Although the cells were seeded at the same density, in the case of the primary MACs not all the seeded cells adhered to the plate and the final number of MACs was less than those for AT2 and TT1 cells. This resulted in an overall reduction in the measured intensity of ROS in MAC (Fig. 2ac) compared with TT1 and AT2 cells (Fig. 2aa and ab).

\section{Effect of nanoparticles on glutathione flux}

As we have limited numbers of primary AT2 and MAC cells, we used TT1 cells as a model to study the effect of oxidative stress on glutathione flux. Cellular glutathione levels (GSH and GSSG) were measured in TT1 cells at 1 and $4 \mathrm{~h}$ after $50 \mathrm{~nm}$ NP exposure (Fig. 3a, b). After $1 \mathrm{~h}$, the GSSG/GSH ratio (indicating the ratio of oxidised GSSG to reduced GSH) was increased, 2-3-fold above nontreated control cells, for all types of NPs (at concentrations of 50 and $100 \mu \mathrm{g} / \mathrm{ml}$ ) reflecting oxidative stress (Fig. 3a-b). By $4 \mathrm{~h}$ (Fig. 3b), control (baseline) TT1 cell GSSG/GSH ratio had increased above that observed at $1 \mathrm{~h}$. There was a further, significant increase in the GSSG/GSH ratio following ANP exposure, even at the lowest concentration of $1 \mu \mathrm{g} / \mathrm{ml}$ (1.5-fold control; $p<0.05, n=3)$, which increased in a concentration dependent manner, reaching $>6$-fold that of unexposed cells $(p<0.001, n=3)$ at $50 \mu \mathrm{g} / \mathrm{ml}$ ANP; this effect was not observed with UNP or CNP. Co-incubation of NPs with NAC for $4 \mathrm{~h}$ prevented the reduction of total cellular glutathione (GSH and GSSG combined; Fig. 3c). The highly significant fall (down to $\sim 10 \%$ of control, $p<$ $0.001, n=3$ ) in glutathione following exposure to $50 \mathrm{~nm}$ ANPs could be markedly prevented by NAC treatment (down to $\sim 67 \%$ of control). A similar trend was also observed in TT1 cells exposed to $100 \mathrm{~nm}$ NPs, although the effect of all three NPs on increased GSSG/GSH ratio at $1 \mathrm{~h}$ was more noticeable than that seen following exposure to the $50 \mathrm{~nm}$ NPs at the same time interval (Fig. 3d). Remarkably, this effect disappeared for UNP and CNP at $4 \mathrm{~h}$, but 


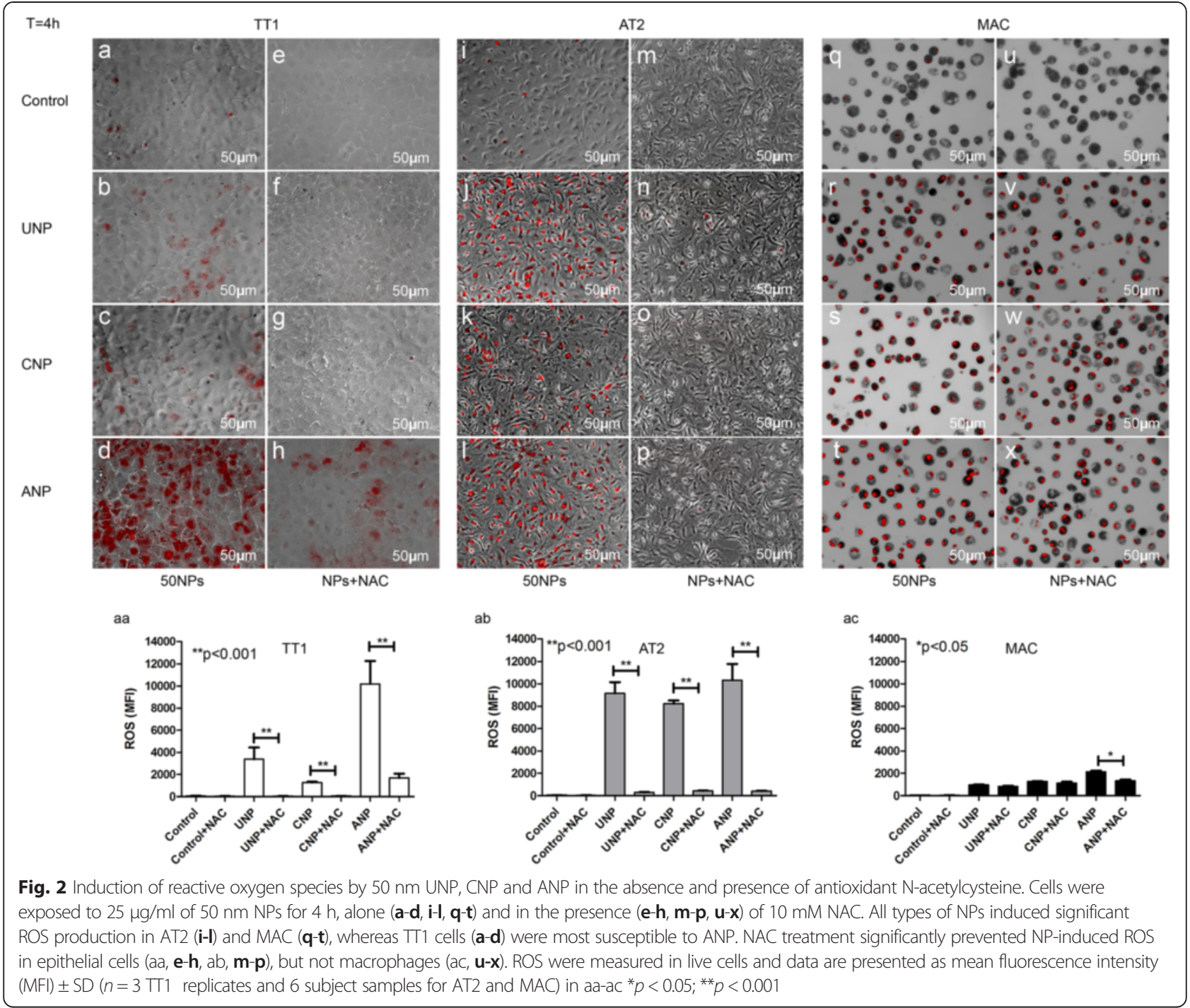

remained at very similar levels for the ANP-exposed cells (Fig. 3e). NAC prevented the reduction of cellular glutathione activated by $100 \mathrm{~nm}$ NPs (Fig. 3f) to a very similar extent to that seen with $50 \mathrm{~nm}$ NPs.

\section{Effect of nanoparticles on mitochondrial function and structure}

Mitochondrial membrane potential and mitochondrial structure of TT1 cells following NP exposure (Fig. 4-5) were observed to compare with changes in ROS production, using MitoTracker fluorescent probe, confocal microscopy and transmission electron microscopy (TEM). The MitoTracker ${ }^{\circ}$ probe reflected mitochondrial membrane potential of the intact mitochondria; a significant decrease in mean fluorescence intensity (MFI), indicating reduction of mitochondrial membrane potential in all cell types exposed to $50 \mathrm{~nm}$ ANPs $(t=4 \mathrm{~h}$, Fig. 4a-c; $p<0.001, n=3$ replicates TT1 and 6 subject samples
AT2 and MAC). This was accompanied by mitochondrial swelling and disruption of the mitochondrial network in ANP-exposed cells (Fig. 4-5), as shown by TEM (Fig. 4, n=60 observed cells) and confocal microscopy (Fig. 5, $n=45$ observed cells). Mitochondrial swelling is a pathology of mitochondria indicated by an increase in volume of mitochondria due to the fluid influx as a result of altered mitochondrial membrane potential. The enlarged size of the mitochondria can be seen at the same magnification (same scale bar) as we show here in Fig. $4 \mathrm{k}, \mathrm{n}$ and $\mathrm{o}$, in comparison to the control cells in Fig. $4 \mathrm{~d}, \mathrm{~h}$ and $\mathrm{l}$. The structure of cristae collapse during the swelling process cannot be detected by the osmium contrast agent when using TEM. We also investigated changes in mitochondrial structure at the lower NP concentration range $(1-25 \mu \mathrm{g} / \mathrm{ml})$ using transmission electron microscopy (TEM) and did not see a difference compared to non-treated cells (data not shown). In the 
normal healthy cells the mitochondria form a network where each mitochondrion is linked to another as seen in control cells in Fig. 5 (the connected green fluorescent feature, control panel). Disconnection of the green fluorescent feature indicated the disconnected mitochondria within the network (change from green connect line to green dot), as seen following exposure to ANP (ANP, green fluorescence panel). Cytochrome C was stained with a red fluorescent signal and when colocalised with the mitochondrial fluorescent green signal, showed yellow. However, in ANP-exposed cells, cytochrome $\mathrm{C}$ is released from the mitochondria and this can be observed in a clear pure red fluorescent signal, indicating loss of mitochondrial integrity and apoptosis (arrows on the right ANP column in Fig. 5). Unlike TT1 cells, all NPs induced ROS production in AT2 cells, however only ANPs induced mitochondrial swelling and loss of mitochondrial membrane integrity, as seen by TEM (Fig. 4k), and breakdown of the mitochondrial network (Fig. 5). This was associated with the release of cytochrome $\mathrm{C}$ (Cyt $\mathrm{C}$ indicated with arrow) within the cells, though this was not as noticeable as that observed in TT1 cells (Fig. 5). Again, all types of NPs induced ROS in MACs; interestingly, unlike the epithelial cells, in MACs, both CNPs and ANPs initiated mitochondrial swelling (Fig. 4-5); however, breakdown of the mitochondrial network and release of Cyt $\mathrm{C}$ could only be observed in MACs exposed to ANPs (see arrows in Fig. 5).

\section{Uptake of nanoparticles by TT1, AT2 and MAC}

TEM and scanning electron microscopy (SEM) were employed to observe nanoparticle-cell interactions and particle uptake (Fig. 6, 7 and 8). We recently showed that the uptake and transport of the same set of latex nanoparticles $(t=4 \mathrm{~h})$ through TT1 cells involved both passive and active transport depending on their size and surface chemistry [16]. The $50 \mathrm{~nm}$ NPs largely entered TT1 cells via passive transport, while the $100 \mathrm{~nm}$ NPs entered mainly via clathrin- and caveolin-mediated endocytosis; $50 \mathrm{~nm}$ ANPs were internalised more rapidly than the UNPs and CNPs [16]. 3-8 \% of $50 \mathrm{~nm}$ UNP and CNP translocated across the TT1 monolayer, without interfering with TT1 monolayer integrity [16]. It was demonstrated that the NPs can traverse between TT1 cells, until they reach a tight junction [16], also shown here in Fig. 7h and which suggests that the integrity of the tight junction (white ti, arrow), and its location, controls the translocation of these NPs between epithelial cells. The aim of the study did not include the effect of NPs on cell monolayer integrity and their translocation; however, work on the TT1 cell in this respect is

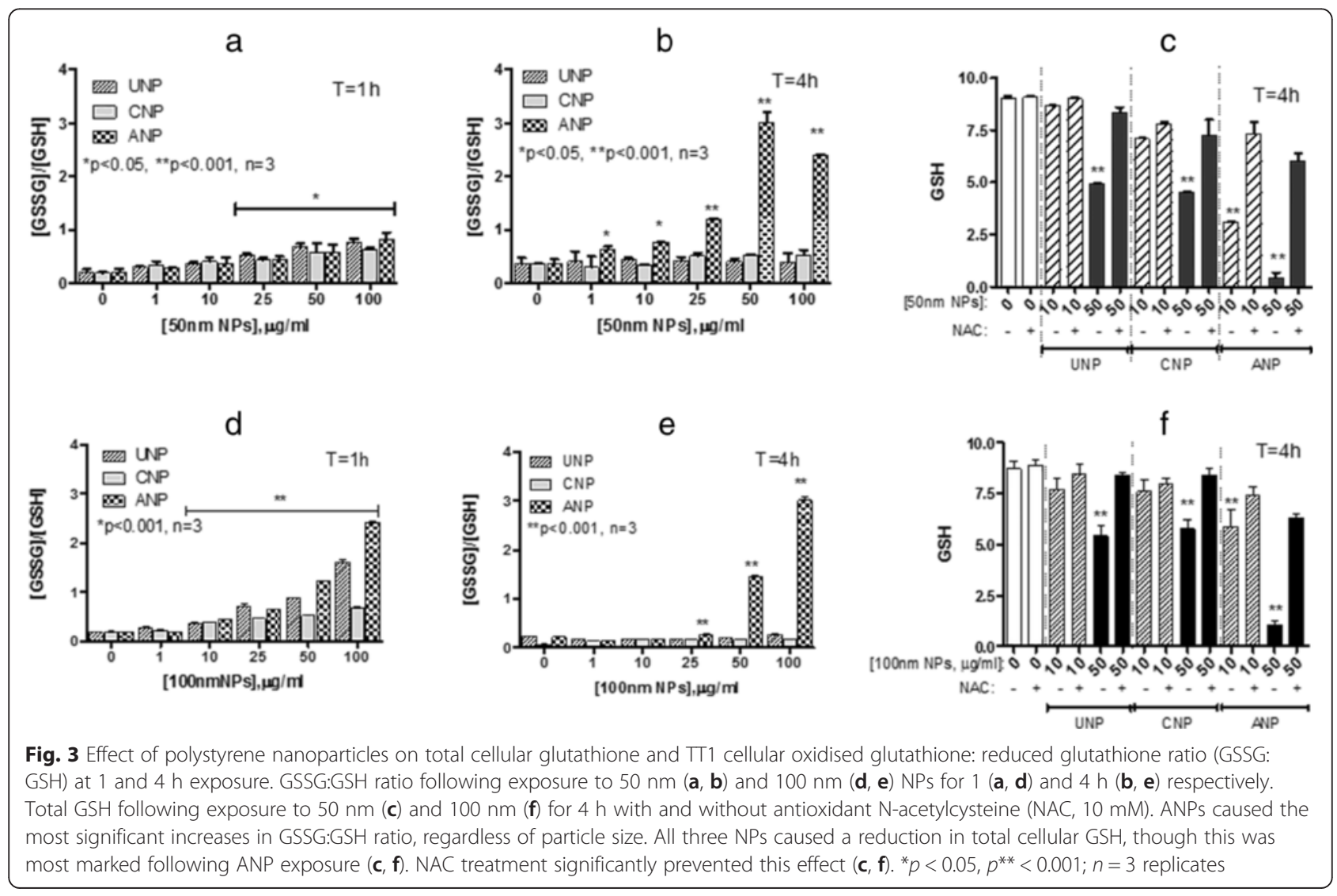




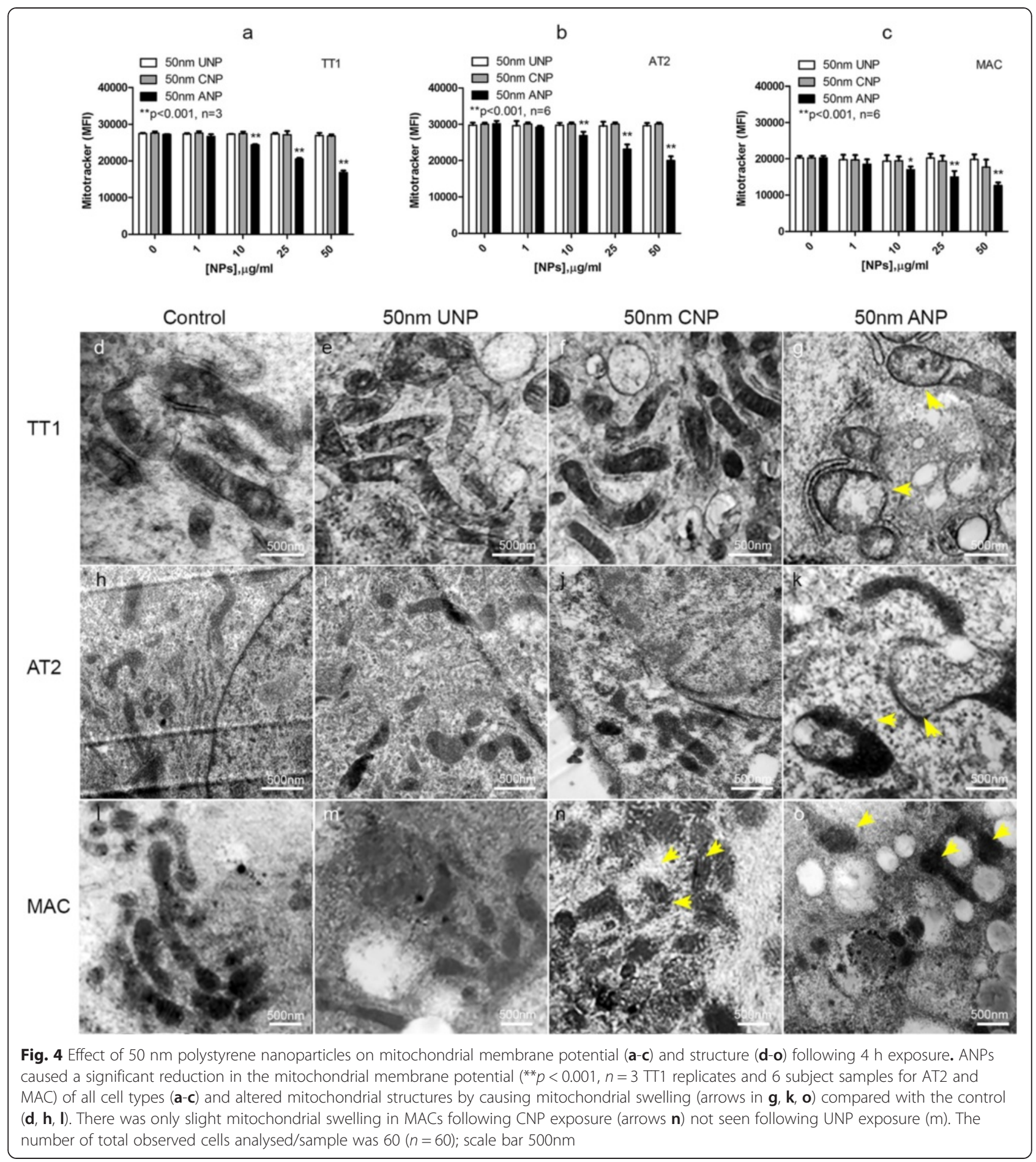

described elsewhere [16]. In the current study, the cells were exposed to $50 \mu \mathrm{g} / \mathrm{ml} \mathrm{NPs}$, as this concentration exhibited very low toxicity (viability was 92-95\%, Additional file 1: Figure S1, [31]) at $4 \mathrm{~h}$ exposure and was a critical concentration at which a change in mitochondrial structure was observed. $40-60 \%$ of TT1 cells and $50-70 \%$ of MACs internalised NPs, whereas only
7-22 \% of AT2 cells contained NPs (Fig. 6m-o). Interestingly, there was little difference between NPfunctionalisation and the number of NPs taken up by each cell type, despite marked differences in cell viability, where ANP were most cytotoxic. Neither was there any difference between the particle sizes. This indicates that surface charge is an important component of the 


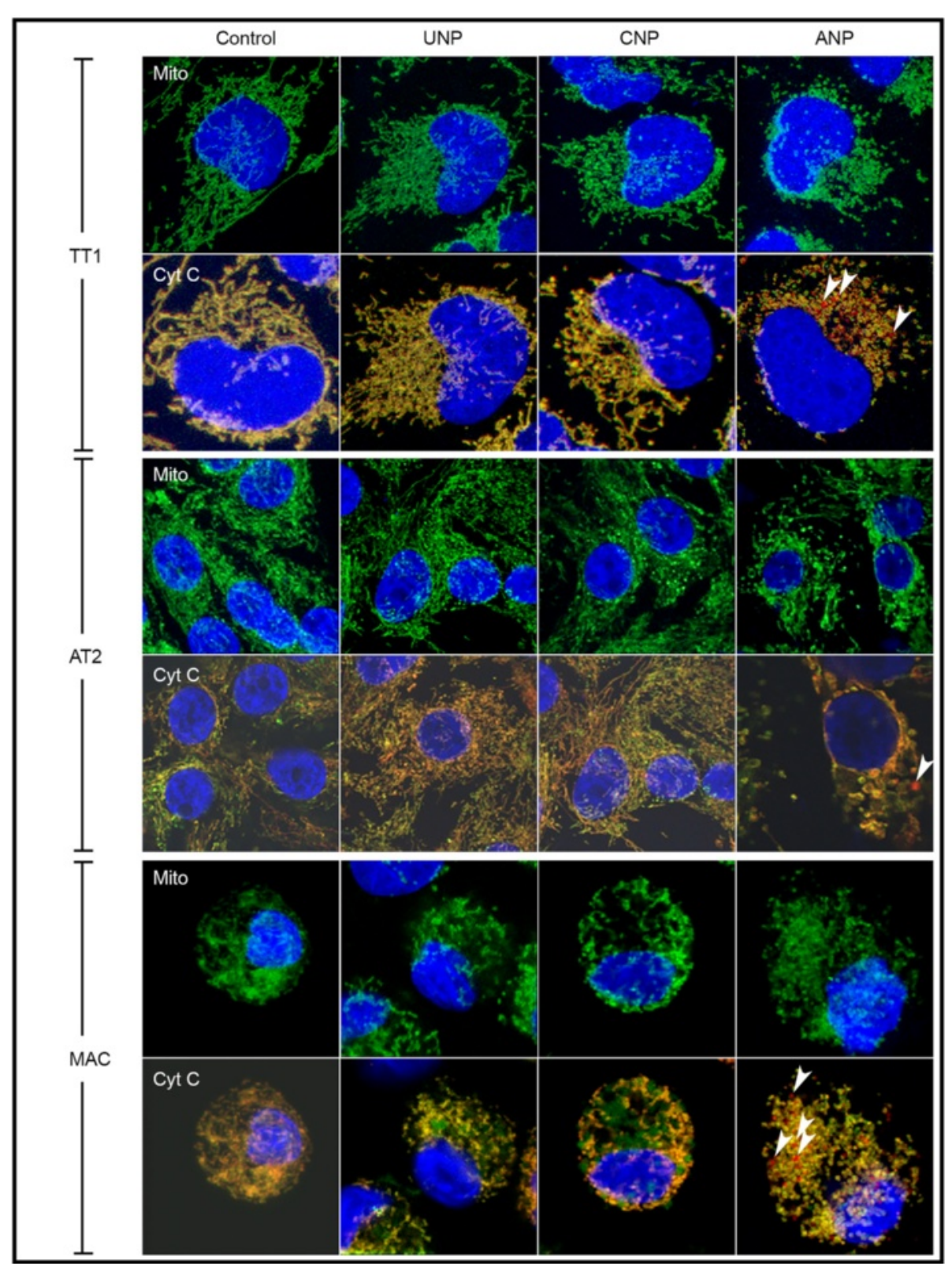

Fig. 5 Effect of polystyrene nanoparticles on cytochrome C (Cyt C) release and the mitochondrial network (Mito) in TT1, AT2 and MAC. Exposure to $50 \mu \mathrm{g} / \mathrm{ml} 50 \mathrm{~nm}$ UNP and CNP had no effect on the release of Cyt $C$ or the mitochondrial network. ANP caused disruption of the mitochondrial network (arrows indicate breakdown of Mitochondria in green) and initiated the release of Cyt C (arrows indicate the red area of (yt $\mathrm{C}$ release) in all cell types). Cell nuclei, mitochondrial networks and cytochrome $\mathrm{C}$ are stained blue, green and red, respectively; $n=45$ cells analysed/sample

cytotoxic effect of the ANP, with the exception of TT1 cells, where $100 \mathrm{~nm}$ ANP-functionalised NPs caused relatively little cytotoxicity. The uptake of NPs by AT2 cells was much lower than that of the TT1 cells and the number of cytosolic NPs in AT2 cells was also much lower than that of the TT1 cells (data not shown). TT1 cells internalised all types of NPs following $4 \mathrm{~h}$ exposure (Fig. 6b-d, m, Fig. 7). The $50 \mathrm{~nm}$ and $100 \mathrm{~nm}$ NPs were observed within TT1 cell vesicles, suggesting active uptake (Fig. 6c-d, Fig. 7). Particles in endo/lysosomal compartments of TT1 were in the form of agglomerates, possibly aggregates (Fig. 6b-d). Cytoplasmic NPs were present as individual particles (Fig. 6b, c, 1 and Fig. 7c-e and k), suggesting passive uptake of NPs or that NPs might escape from endo/lysosomes. Use of the LysoTracker ${ }^{\circ}$ fluorescent probe indicated an effect of NPs on lysosomal membrane integrity. The decrease in mean fluorescence intensity (MFI) of the probe indicated a decrease in the number of intact lysosomes within the cells 


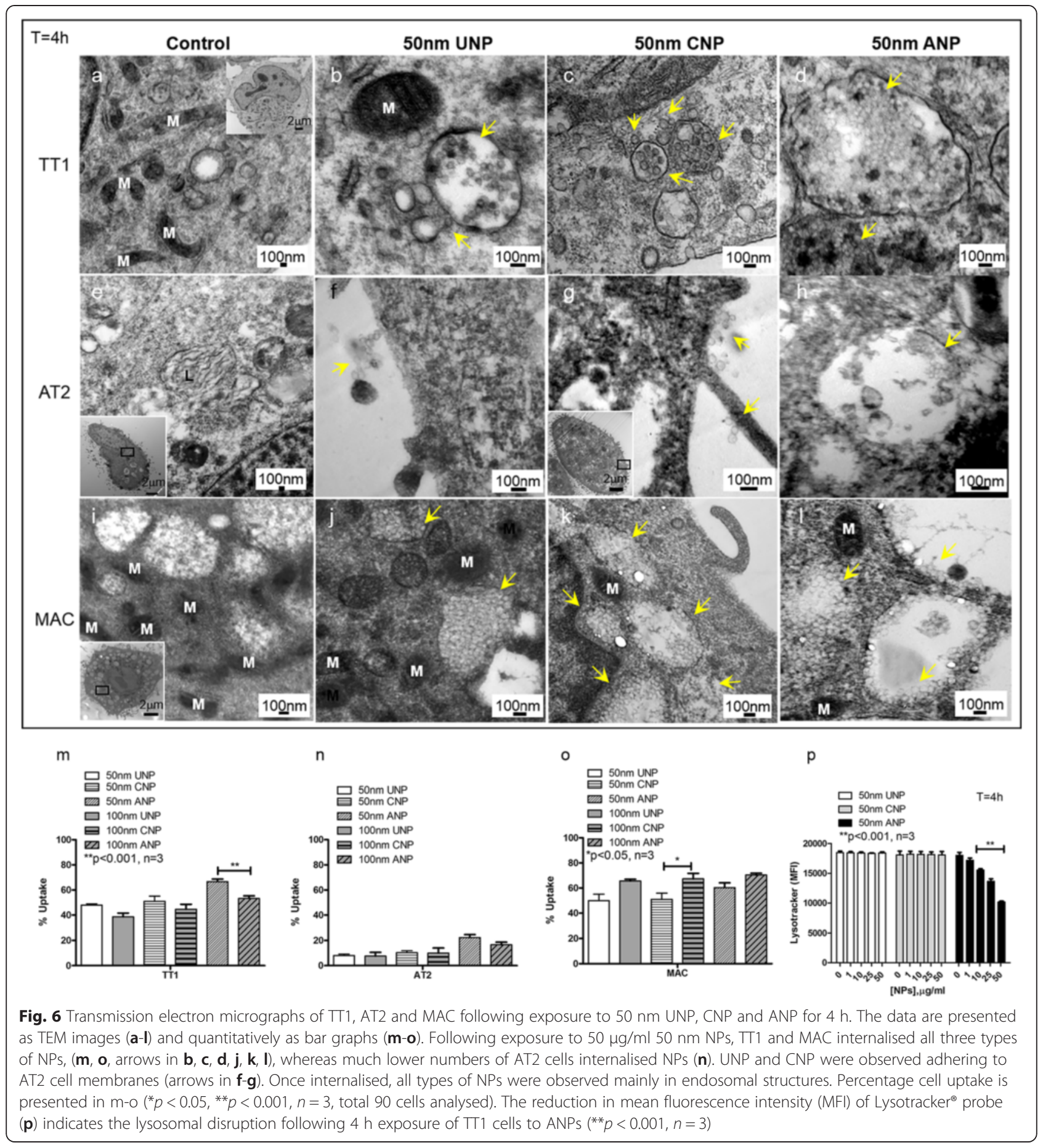

following NP exposure. ANPs, but neither UNPs nor CNPs, caused a significant reduction in the MFI of LysoTracker ${ }^{\circ}$ $(p<0.001, n=3$, Fig. $6 p)$ suggesting that the amine-surface modified NPs precipitated lysosomal membrane damage and, subsequently, escaped to the cytoplasm possibly via a 'proton sponge' mechanism [36]. We previously reported that ANPs caused pore formation in the cell membrane which may be one mechanism of passive uptake of $50 \mathrm{~nm}$
ANPs [31]. In addition, NPs (Fig. 7c and k) appeared to adhere to the TT1 cell membrane and penetrate into the cell cytoplasm. The uptake of individual particles was also observed to occur at the lateral, paracellular and cell-cell interface, where NPs had tracked between the cells, up to the tight junction, before translocation as individual NPs across the cell membrane (Fig. $7 \mathrm{~d}$-e and h-i) as we previously reported [16]. It is difficult to assess whether particles 


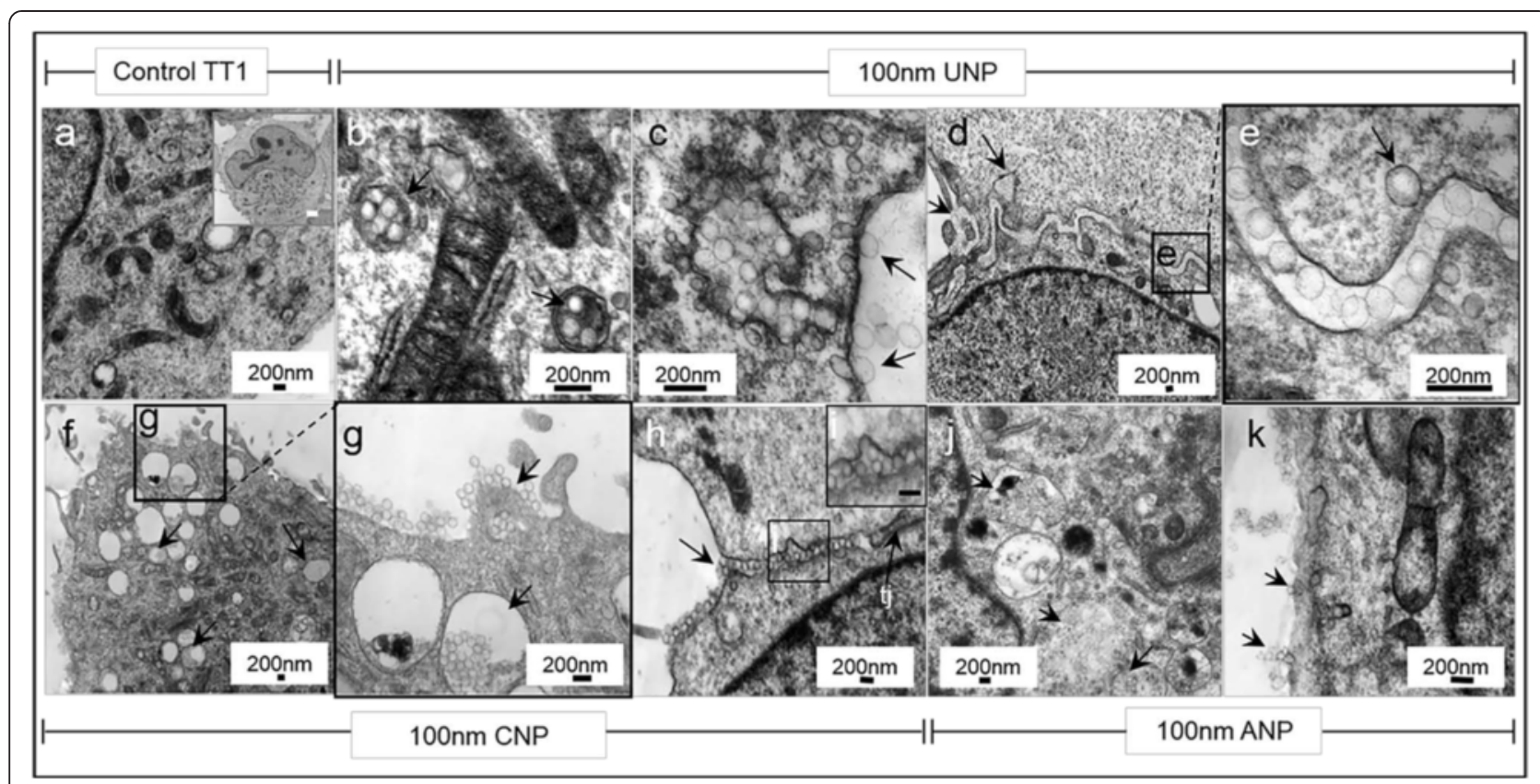

Fig. 7 Interaction and uptake of $100 \mathrm{~nm}$ polystyrene UNP. CNP and ANP by $\Pi 11$ cells $4 \mathrm{~h}$ after exposure. Following exposure to $50 \mu \mathrm{g} / \mathrm{ml} \mathrm{NPs}$, compared to non-exposed TT1 cells (a), UNPs were taken up via endocytosis as an agglomerate (arrows in $\mathbf{b}$ ) and as individual particles (arrows in c). UNPs were also observed paracellularly and were taken up individually (arrows in $\mathbf{d}$-e). Similar observations were made following $T 11$ cell exposure to CNPs (f; arrows in $\mathbf{g}$ indicate endocytosis and macropinocytosis). The CNPs also travelled paracellularly (left arrow in $\mathbf{h}$, right arrow indicates tight junction-tj). The ANPs were taken up via endocytosis as agglomerates (arrows in $\mathbf{j}$ ) and individually (arrows in $\mathbf{k}$ ), but few were observed paracellularly. The percent cell uptake of all NPs by all cell types is shown in Fig. $6 \mathrm{~m}$-o in comparison with the $50 \mathrm{~nm}$ NPs. Scale bars in $\mathrm{a}-\mathrm{k}$ are $200 \mathrm{~nm}$; a total of 90 cells were examined

that appear to be within the cytosol are membrane-bound. We used a sample preparation and staining technique, with osmium, uranyl acetate and lead citrate post-stain, to specifically identify membranes and believe that any membranes, including vesicular membranes should have been apparent. Thus, we believe that some particles appear to be free within the cytosol. And, importantly, this latter, paracellular process was less obvious with ANP suggesting different uptake mechanisms (Fig. 7j-k). In contrast to TT1 cells, most of which internalised all types of $50 \mathrm{~nm}$ NPs, only a small proportion of AT2 cells (6-20 \% from Fig. 6, $[16,29])$ were found to contain NPs (Fig. 6f-g, n). Intracellular ANPs were only found in the endosomal compartment (Fig. 6h), indicating active uptake.

To observe how NPs interact at the cell surface, we used scanning electron microscopy (SEM, Fig. 8) to observe the cell-nanoparticle interface. We previously reported that latex NP could initiate the protruding of microvilli in live cell experiments of TT1 interactions $[31,37]$ using scanning ion conductance microscopy [31]. A similar effect was observed here with AT2 (Fig. 8); the presence of all types of $50 \mathrm{~nm} \mathrm{NPs,} 50 \mu \mathrm{g} /$ $\mathrm{ml}$, induced microvilli formation, possibly modifying NP interaction with AT2 cells, as the microvilli protruded and surrounded the NPs (Fig. 8a-d; [31]). Both agglomerated and individual NPs adhered to the cell membrane, amongst the cell surface microvilli, which were more dense and co-localised with the NPs (Fig. 8d, f and h). All types of $50 \mathrm{~nm}$ NPs were detected within the vesicle compartments of MACs, as agglomerates, suggesting phagocytic uptake (Fig. 6k, o). SEM indicated altered MAC morphology after exposure to NPs (Fig. 8i-o). UNP-induced changes in MAC morphology were of the classic activated macrophage, exhibiting extensive filopodia (Fig. 8j-k); in contrast, MACs exposed to CNP and ANP were devoid of filopodia and showed blebbing of the cell membrane (Fig. 8l-o), possibly prior to apoptotic cell death. All three NPs were found adhered to the cell membrane of MACs (Fig. 8k, m, o).

\section{Discussion}

In this study, the response of human pulmonary alveolar epithelial cells and alveolar macrophages to NPs of different size (50 and $100 \mathrm{~nm}$ diameter) and surface modification (UNP, ANP and CNP, Table 1) were examined. Both size and surface charge are crucially important determinants of alveolar cell responses. In addition, the striking differences between cell types in their interactions with, and reactions to, nanoparticle exposure, are likely reflecting their functional role within the alveolus.

The ability of polystyrene latex NPs to induce cell death, cellular oxidative stress and oxidative damage 


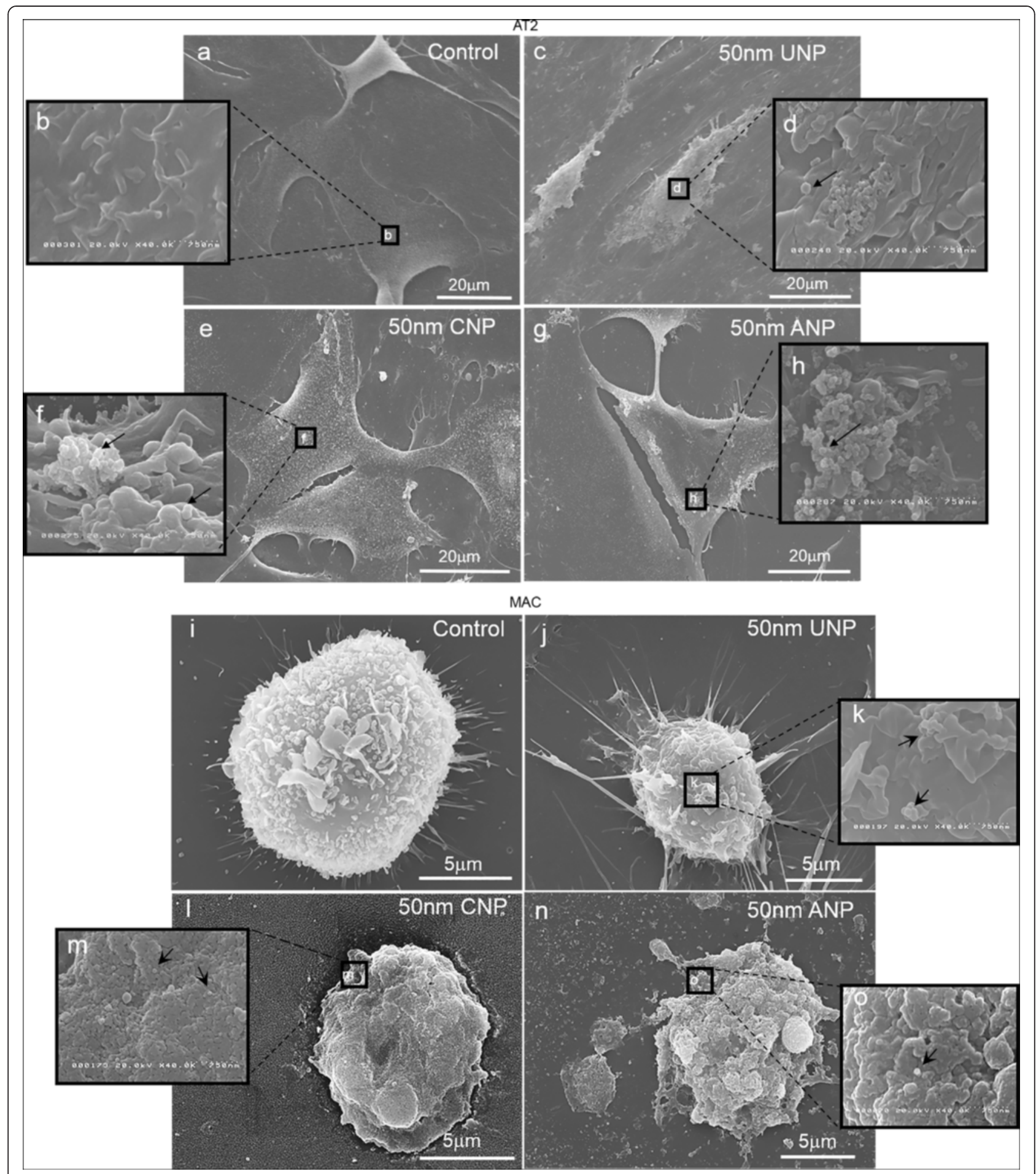

Fig. 8 Interaction of UNP, CNP and ANP with the cell surface membrane of AT2 cells and MAC. AT2 cells exposed for $4 \mathrm{~h}$ to $50 \mathrm{\mu g} / \mathrm{ml}$ of $50 \mathrm{~nm}$ polystyrene UNP (c-d), CNP (e-f) and ANP ( $\mathbf{g}-\mathbf{h})$ compared to the non-treated control AT2 (a-b). Both individual and aggregated forms of all types of NPs were observed on the cell surface membrane of AT2 cells, situated amongst microvilli (arrows in $\mathbf{d}, \mathbf{f}, \mathbf{h} ; n=60$ cell observations). Scanning electron micrographs of control MAC (i) and MAC exposed to $50 \mathrm{\mu g} / \mathrm{ml}$ of $50 \mathrm{~nm}$ polystyrene UNP (j-k), CNP (I-m) and ANP (n-o) for 4 h. MACs were activated following exposure to UNP (j-k), CNP (I-m) and ANP ( $\mathbf{n}-\mathbf{o})$. Both individual and aggregated forms of NPs were observed on the cell membrane of MACs (arrows in $\mathbf{k}, \mathbf{m}, \mathbf{o}$ ). UNP triggered filopodia formation, while CNP and ANP initiated membrane blebbing. All type of NPs were observed in association with cell surface microvilli 
were revealed. The increase in hydrodynamic diameters of all types of NPs in tissue culture medium DCCM1 indicated that these particles bind to proteins in the medium, mostly albumin, as described elsewhere [30, 31 . Thus the surface charge changed (zeta values) to be between -11 and $-15 \mathrm{mV}$ showing less difference between the different NP surface charges. Nevertheless, there were significant differences in the bioreactivity of these particles between the different cell types. One reason for this may be that albumin forms a soft corona that is easily displaced and, on interaction with specific components of the cell membrane [38,31], the particles then exhibit their original surface chemistry. Although, the RPMI did not contain serum and protein, the aggregation or agglomeration of NPs could be observed with $100 \mathrm{~nm}$ NPs (all types) and $50 \mathrm{~nm}$ ANPs with zeta values between -16 and $-27 \mathrm{mV}$. This suggested that salt and amino acids within RPMI could be involved in the aggregation or agglomeration. Interestingly, however, when IL-6 and IL-8 release (Additional file 1: Figure S5S6) was examined in AT2 cells, the response was the same for all three particles, despite their surface chemistry. We recently showed that these NPs adsorb SP-D from human lung secretions [39], and we know that in this human AT2 cell model, surfactant is released [30]. We suggest that in this case, the albumin has been displaced by components of surfactant or other AT2 cell secretions that then triggers an identical response in the AT2 cells. We appreciate that it might be possible to avoid the effects of albumin adsorption from the medium by using air-liquid interface cultures and aerosolised particles [40]. Despite this, in this study we have shown markedly different responses between cells of the alveolar unit when challenged with NPs with different surface chemistry which we believe are important, and which we intend to study at an air liquid interface in future.

Nevertheless, the original surface charge of the polystyrene NPs was extremely important in their bioreactivity. As we and others have shown previously [16, 31, 41], amine-modified NPs are particularly cytotoxic at high concentrations [16, 17]. Even at lower, non-cytotoxic concentrations, $50 \mathrm{~nm}$ ANPs induced significant oxidative stress in all three cell types over a period of $24 \mathrm{~h}$. Although UNP and CNP did not induce significant cell death, both these particles induced a high ROS response in AT2, similar to that observed following ANP exposure (Fig. 2; Additional file 1: Figure S7), but less so in TT1 cells, illustrating that induction of ROS varies according to the target cell. Addition of NAC significantly $(\mathrm{p}<$ $0.01, n=3$ (TT1), 6(AT2)) reduced ROS production in TT1 and AT2 cells. MAC produced the lowest ROS levels both at baseline and following NP, likely due to the lower cell density of MACs compared to the TT1 and AT2 cells (Fig. 2). Therefore cells situated adjacently in situ responded quite differently to the same stimulus; furthermore, high ROS is not always linked to cell death. By using two types of dye tracking ROS, we found that ROS production by TT1 cells involved peroxide, singlet oxygen and superoxide (as both dyes exhibited a similar trend) whereas the ROS produced by AT2 and MAC was mainly superoxide. These findings indicate different oxidative stress processes between the cell types. The role of cationic NPs in induction of oxidative stress has previously been observed $[17,42,43]$, using a variety of cell lines, both immune and structural cells. Induction of oxidative stress in a macrophage cell line by aminemodified NPs [17], amine-modified silicon nanoparticles $\left(\mathrm{SiNP}-\mathrm{NH}_{2}\right)$, resulted in cell death accompanied by ROS production [43] which was not observed with neutral and anionic silica nanoparticles. A similar phenomenon was described for the RAW 264.7, phagocytic cell line, exposed to amine-modified polystyrene nanoparticles [17], which lead to apoptotic cell death, in contrast to that in BEAS2-B cells, which exhibited necrotic cell death. However, in another study using cationic and anionic CdSe quantum dots [43], the cationic particles conferred the most toxicity against primary human airway epithelial cells, but this did not parallel ROS induction [44].

Increased TT1 cell ROS activation was accompanied by a reduction in total cellular glutathione and an increase in the ratio of oxidised glutathione to reduced glutathione (GSSG:GSH; Fig. 2, 3), particularly on exposure to $50 \mathrm{~nm}$ ANPs, accompanied by cell death, suggesting that increased ROS was the cause of cell death. Comparing the 50 and $100 \mathrm{~nm}$ NPs, the $50 \mathrm{~nm}$ NPs initiated a faster and higher ratio of [GSSG]: [GSH] which peaked at $t=30 \mathrm{~min}$ following exposure (data not shown), before falling at $t=1 \mathrm{~h}$ (Fig. 3); this then increased after $2 \mathrm{~h}$ exposure, peaking at $4 \mathrm{~h}$ (Fig. 3). A slower response was observed with TT1 cell exposed to $100 \mathrm{~nm}$ NPs which showed no effect at $30 \mathrm{~min}$ following NP exposure (data not shown) before the [GSSG]: [GSH] was increased markedly for all NPs at $1 \mathrm{~h}$, above that for the $50 \mathrm{~nm} \mathrm{NPs}$, but which then fell for UNP and CNP, but for ANP peaked at $t=4 \mathrm{~h}$ exposure. This suggests a dynamic flux of [GSSG]:[GSH] which is temporal and related to particle size and charge. However, NAC treatment reduced oxidative stress but did not markedly ameliorate $50 \mathrm{~nm}$ ANP-induced TT1 cell death, again suggesting that induction of ROS is not always responsible for cell death. An intriguing discovery was that co-application of NAC could significantly reduce or prevent polystyrene-induced ROS production in epithelial cells, but had much less effect on ROS production by MACs (Fig. 2). This may be due to the low baseline of ROS production in MACs exposed to NPs, 
reflecting lower cell numbers and therefore reducing the sensitivity; a significant protective effect of NAC was only observed with MACs exposed to ANP $(p<0.05$, $n=3)$. Xia et al. [17] reported that NAC could not protect RAW264.7 exposed to amine-modified polystyrene latex at $8 \mathrm{~h}$, but this protective effect was re-observed at $16 \mathrm{~h}$ indicating time dependent process. NAC may protect cells because: i) NAC is a free radical scavenger and precursor of GSH and would be expected to protect GSH as well as replenish used GSH or supplement existing GSH; ii) NAC might also activate anti-apoptotic signal transduction pathways involved in cell survival $[45,46]$. The inability to prevent polystyrene NPinduced ROS in MACs using NAC suggests that either the depletion of GSH was greater than that provided by supplementary NAC treatment, and/or that an alternative process is causing ROS production.

Nevertheless, ROS markedly increased in AT2 and MAC following exposure to all types of NPs indicating that induction of ROS was an important consequence of NP exposure, but supporting the proposal that other mechanisms are involved in cell death, which was largely a feature of ANP exposure. Previous studies indicate that early mitochondrial injury is an important feature of amine-modified polystyrene NP-induced cell death [42], where mitochondrial integrity and structure were affected. Thus, in a comparative study of the effects of amine-modified, $60 \mathrm{~nm}$ polystyrene particles on RAW 264.7 and BEAS2-B cell lines, the mitochondria were identified to be a target but the cellular reaction differed. Mitochondria in RAW 264.7 cells were swollen and lacked cristae exhibiting apoptotic cell death. In contrast, in BEAS2-B cells, the mitochondria were condensed and eventually disappeared exhibiting necrotic cell death. These differences between cellular responses to the same amine-modified nanoparticles were attributed to alternative modes of nanoparticle uptake, fate and bioreactivity within the cell. Mitochondria are considered to be the most important organelles in producing ROS and are also the first targets for ROS. It is possible that overproduction of ROS might damage the structure of mitochondria, triggering cell death via mitochondrial uncoupling and the release of cytochrome $\mathrm{C}$ and other apoptotic factors [47]. Indeed, in all three cell types, $50 \mathrm{~nm}$ ANP induced ROS, the swelling and breakdown of the mitochondrial network, and release of cytochrome C (Figs. 2, 4, 5), an important component of the apoptotic pathway. These findings are consistent with the increase in ROS and GSSG/GSH ratio in TT1 cells exposed to ANPs. This also corresponds with our previous observation that ANP exposure induced the release of TT1 cell caspase 9 and 3/7 suggesting that induction of the intrinsic apoptotic pathway is the major mechanism of ANP-induced TT1 cell cytotoxicity [31]. From our previous findings and this study, we have proposed a pathway of ANP-induced TT1 toxicity. Based on the findings in this study we suggest that this process may be applied with AT2 cells and MACs. However, we also observed LDH release, suggesting necrotic cell death, but which might have been due to secondary necrosis of apoptotic cells in the absence of efferocytosis and clearance of apoptotic cells. In contrast to these observations with ANPs, although UNP and CNP triggered increased ROS, notably in AT2 and MAC, this did not impact on mitochondrial integrity or cell viability, indicating the significance of surface chemistry in cellular bioreactivity.

As mentioned earlier, the cellular response to aminemodified particles is also believed to relate to cellular uptake mechanisms and quantity of particles internalised [35, 45-47]. Here, we studied the NP uptake of TT1 and another two cells types (AT2 and MACs) using TEM, an accurate but time consuming technique to quantify the percent of NP uptake. We previously employed other rapid techniques including flow cytometry, confocal microscopy, transwell plate studies to quantify particle uptake and transport across TT1 cells [16]. Our findings adds more information on NP uptake and help to complete the picture. All types of NPs were found in a high proportion of TT1 and MACs, whereas in AT2, only ANP were observed in a very low proportion of cells. One mechanism by which TT1 cells internalise molecules is by endocytosis, which may lead to transfer of molecules across the alveolar gas-blood barrier, via caveolae and clathrin coated vesicles [48, 49, 16]; the presence of 50 and $100 \mathrm{~nm}$ NPs in TT1 cells, as small and large agglomerates within endosomal vesicles, reflects this and suggests that another mechanism involves macropinocytosis. Cytoplasmic, individualised CNP and UNP could be due to passive uptake of the individual NPs (Fig. 7); these NPs may penetrate intracellular cell membranes or they might passively diffuse through cell membranes, without involving cellular energy. However, TEM cannot indicate whether the NPs are fusing with the phospholipid membrane or whether they are attached to it. Further investigation using high resolution TEM would be useful to establish this. Despite internalisation by TT1 cells, CNP and UNP were not overtly toxic. ANP were taken up apically by TT1 cells; cytoplasmic ANPs may reflect transfer via cell membrane pore formation, as demonstrated by us and others previously $[31,50]$. We hypothesise that, at high concentrations, excessive membrane damage could cause cytotoxicity [51, 52]. Alternatively, release of ANPs due to endosomal rupture could occur [53, 54]; cytosolic ANPs in TT1 could initiate cell death, as suggested previously [31, 42].

Other studies describe the impact of cationic nanoparticle surface modification on uptake, which is consequently being used as a drug targeting strategy; cationic surface 
modification of nanoparticles, including poly(D,L-lactideco-glycolide)/lipid-based nanoparticles, silica-titania hollow nanoparticles, iron nanoparticles, latex nanoparticles and megitoliposomes, enhanced their uptake by a wide range of cell lines [55-59]. However, endosomal and passive uptake of cationic nanoparticles may account for the observed toxicity of these particles, as described here, and elsewhere $[17,42]$. A high density of amino surface groups on the surface of ANPs may trigger escape from endosomes and phagosomes by the so called 'proton sponge' phenomenon $[37,53,54]$. This could enhance the possibility of a direct interaction between ANPs and cell organelles, resulting in cell death. In contrast, for carboxyl-modified polystyrene nanoparticles, Fröhlich et al. [60] report that endosomal/ lysosomal $20 \mathrm{~nm}$ carboxyl-modified nanoparticles within EAhy926 endothelial cell lines caused alteration of lysosomal enzyme activity but did not cause any lysosomal swelling and disruption. Such processes could explain the differences in cytotoxicity of neutral, cationic and anionic polystyrene in the present study. Thus, lysosomal disruption and release of potent lysosomal enzymes could contribute to ANP-induced cell death, as these enzymes have been shown to activate apoptotic cell death pathways, for example via direct damage to the mitochondria and proteolytic activation/inhibition of cellular processes.

\section{Conclusion}

In this study of the response of three human cells that constitute the alveolar unit to $50 \mathrm{~nm}$ and $100 \mathrm{~nm} \mathrm{NPs}$, we have shown marked differences in the cellular responses depending on size and surface chemistry of NPs, and also on the type of cells. An important finding was that amine functionalization caused cytotoxicity in all three cell types, involving a process of induction of oxidative stress, mitochondrial disruption and Cyt $\mathrm{C}$ release, and likely leading to apoptotic cell death. Most of epithelial type 1 cells and macrophages internalised ANPs reflecting their functions in translocation of biomolecules across the gas-liquid interface and removal of organic and inorganic material from the alveoli, respectively. This implies that particle uptake is a pre-requisite to cell death, however, most AT2, largely secretory cells, showed much lower ANP internalisation, and yet ANPs were cytotoxic, indicating that there might be alternative cell surface-dependent mechanisms of cellular signalling that trigger oxidative stress and cytotoxicity. On the other hand, if cell death requires ANP uptake, followed by rapid death of the AT2 cells which contain the ANP, and survival of those that do not take up ANP (cell viability $70-80 \%$ at ANP concentration of $50 \mu \mathrm{g} / \mathrm{ml}$ ), this would confound the use of electron microscopy to relate ANP uptake to AT2 cell death because the dynamic response at cell-nanoparticle interface was observed. Further studies are required. Importantly, UNP and CNP did not induce marked cell death even though they were internalised by TT1 cells and MACs, and they induced ROS, mostly in AT2 cells and MACs. This suggests that the focus on induction of oxidative stress as a marker of cytotoxicity and therefore increased hazard to inhaled nanomaterials does not reflect the import of raised oxidative stress in protection from such challenges. Thus, NP uptake does not automatically relate to cytotoxicity, although induction of ROS suggests that other cellular processes might be harnessed. In vivo, the epithelial liquid lining layer contains significant concentrations of non-enzymatic antioxidants, which this study of NAC suggests would protect alveolar epithelial cells from NPinduced ROS. Type 1 cells cover $95 \%$ of the alveolar surface and this unique study indicates that these cells are most robust in the presence of neutral and carboxylmodified nanoparticles, which enter the cells. We suggest that type 1 cells provide an excellent target for inhaled NP drug delivery systems, both with the lung as a target, and for systemic delivery, being in close apposition to the microvasculature.

\section{Methods}

Culture of human immortalized alveolar epithelial type 1 cells (TT1)

The immortal TT1 cells were created from primary human alveolar epithelial type 2 cells isolated from the healthy region of tissues as previously described [29] which shows the same characteristics and phenotype as AT1 in vivo [29]. The TT1 cells were routinely grown in defined cell culture medium (DCCM1, Cadama, UK) supplemented with $10 \%$ new-born calf serum (NCS) and $1 \%$ penicillin/streptomycin/l-glutamine (PSG). They were seeded at a density of $0.5 \times 10^{6}$ cells/well in 24-well plates until they reached confluence, within 2 days. $24 \mathrm{~h}$ prior to NP exposure, the cells were serum starved.

\section{Isolation of primary human alveolar macrophages (MAC)}

The tissues used in this study were surplus tissue obtained following resection for lung carcinoma and written informed consent was obtained for all samples. The study was carried out with the approval of the Royal Brompton and Harefield Ethical Committee (Ref: 08/ H0708/73). MAC were isolated from lung tissue as previously described [61]. Cells were isolated from a minimum of six different donors per experiment $(n=6)$. The lung tissues were perfused with $0.15 \mathrm{M}$ sterile sodium chloride solution until the draining lavage became clear. The perfused saline was collected into $50 \mathrm{ml}$ conical Falcon tubes and centrifuged at $1300 \mathrm{rpm}$ (rotor radius is $168 \mathrm{~mm}$ ) for $10 \mathrm{~min}$ at $20{ }^{\circ} \mathrm{C}$. The cell pellet was re-suspended in serum-free RPMI culture medium supplemented with $1 \%$ penicillin/streptomycin/l-glutamine (PSG) and plated onto 96 well culture plates at $0.2 \times 10^{6}$ 
cells/well (and $0.5 \times 10^{5}$ cells/well in 12-well plates for oxidative stress and uptake studies). These MACs settle down and adhere to the plate within $3 \mathrm{~h}$ of seeding. The medium was removed and the cells were was carefully rinsed with phosphate buffer solution (PBS) to remove the non-adherence cells. The cells were maintained in serumfree RPMI medium (0 \% serum in RPMI) supplemented with $1 \%$ PSG and incubated in $5 \% \mathrm{CO}_{2}$ at $37{ }^{\circ} \mathrm{C}$.

\section{Isolation of primary human alveolar epithelial type 2 cells} (AT2)

The tissue remaining following the MAC isolation was then used for AT2 cell isolation as previously described by Witherden et al. [62]. Cells were isolated from a minimum of six different subjects per experiment $(n=$ 6). Cells were suspended in DCCM1 medium (Cadama, UK) supplemented with $10 \%$ NCS and $1 \%$ PSG and they were seeded on 96 well culture plates at $0.1 \times 10^{6}$ cells/well (and $0.5 \times 10^{5}$ cells/well in 12-well plate for oxidative stress and uptake studies). The wells were pre-coated with $1 \%$ type I collagen solution (PureCol, Netherlands). Cells reached confluence $48 \mathrm{~h}$ after seeding, they were thoroughly characterised using electron microscopy illustrating their cuboidal morphology, lamellar bodies, tight junctions and microvilli [30, 62]. They were also stained positively for the AT2 cell marker alkaline phosphatase and expressed surfactant proteins A and C. Their retained the AT2 cell phenotype for up to 6 days $[30,62]$ and were used in these studies within three days of seeding. After reaching confluence, the cells were serum starved for $24 \mathrm{~h}$ before the exposure.

\section{Particle size and zeta potential}

The $50 \mathrm{~nm}$ and $100 \mathrm{~nm}$ latex polystyrene nanoparticles (NPs), unmodified, carboxyl and amine-modified were purchased from Sigma Aldridge, UK. NPs were suspended in distilled water (DW) and DCCM1 culture medium without serum, (Cadama, UK) at a final concentrations of $10 \mathrm{mg} / \mathrm{ml}$. NPs were vortexed and filtered through a $0.22 \mu \mathrm{m}(50 \mathrm{~nm}$ NPs $) / 0.45 \mu \mathrm{m}(100 \mathrm{~nm})$ membrane filter. The samples were sonicated in a sonication water bath for 2 min just prior to measuring size and zeta potential using a Zetasizer Nano (Malvern Instruments Ltd, UK).

\section{Exposure of cells to NPs}

MACs and TT1 cells were routinely seeded and cultured into each well of a 96-well or 24-well plates, in RPMI 1640 serum-free medium (MACs) and DCCM1 (TT1), $10 \%$ new born calf serum (NCS), and $1 \%$ PSG, respectively. AT2 cells were seeded at the same density on the collagen coated plate as described above. At confluence, $24 \mathrm{~h}$ prior to NP exposure, the medium of TT1 and AT2 was replaced with serum-free DCCM1. For MACs the cells were washed twice time to remove non-adhering cells and red blood cells before the exposure. The cells were exposed to $0-100 \mu \mathrm{g} / \mathrm{ml}\left(0-50 \mu \mathrm{g} / \mathrm{cm}^{2}\right)$ NP for 4 and $24 \mathrm{~h}$ at $37{ }^{\circ} \mathrm{C}$ with or without $\mathrm{N}$-acetyl cysteine (NAC), $10 \mathrm{mM}$, in serum free medium.

\section{Cell viability (MTT assay)}

Following the 24-h exposure period, the medium was removed, the cells were thoroughly washed with PBS to remove residual NPs and then incubated with 3-(4, 5Dimethylthiazol-2-yl)-2, 5-diphenyltetrazolium bromide (MTT) in fresh medium, $50 \mathrm{mg} / \mathrm{ml}$, for $2.5 \mathrm{~h}$ at $37{ }^{\circ} \mathrm{C}$. The medium was removed and $200 \mu$ l of DMSO was added to each well to dissolve the cells and the insoluble formazan dye. The plate was placed on a rotary shaker briefly and centrifuged at 14,000 g for $20 \mathrm{~min}$ to remove any residual NPs, before reading the optical density of the supernatants using a Thermomax microplate reader at $570 \mathrm{~nm}$ (MTX Lab Systems, USA). The viability of the cells exposed to NPs was then calculated as a percentage of the non-treated control cells (exposed to PBS). To determine the effect of NPs on the MTT assay, NPs were: (i) added to unexposed, control cells immediately before the assay, or (ii) added to the assay system following DMSO dissolution, and then processed identically to cellular experimental cells. The assay solutions were centrifuged at $14,000 \mathrm{~g}$ to remove the NPs from suspension prior to determination of the optical density of the supernatant, to avoid interference in optical density readings by NPs; experiments were carried out in triplicate for TT1 cells $(n=3)$ and $n=6$ for the AT2 cells and MAC.

\section{Lactate dehydrogenase assay (LDH)}

After 4-h and 24-h exposure periods, the conditioned medium was collected and centrifuged at 14,000 $\mathrm{g}$ for $20 \mathrm{~min}$ to remove the cell debris and residual NPs. LDH was analysed using the Cytotoxicity Detection kit PLUS (LDH; Roche, UK). For the positive control (100\% LDH release), $2 \mu \mathrm{l}$ of cell lysis reagent (provided with the kit) was added into medium of non-treated cells and the cells were further incubated for $15 \mathrm{~min}$ before the medium, containing the $\mathrm{LDH}$ released from the lysed cells, was collected for centrifugation and LDH assay performed following the manufacturer's protocol. $50 \mu \mathrm{l}$ of the substrate (provided with the kit) was added to $50 \mu \mathrm{l}$ of sample medium and the plates were incubated for $45 \mathrm{~min}$ before the stop solution was added. For the control and the substance control, a known concentration of $\mathrm{LDH}$ standard $(0.05 \mathrm{U} / \mathrm{ml})$ was incubated with a sample of DCCM1 medium, with or without increasing concentrations of the NPs and the assay performed in an identical manner. The data were collected by reading 
optical absorption at a wavelength of $492 \mathrm{~nm}$ using a Thermomax microplate reader (MTX Lab Systems, USA). There was no significant interference by the NPs because they were removed by centrifugation prior to reading the optical absorption, as described above. Three replicate experiments were performed for TT1 and six replicate experiments were performed for AT2 and MAC.

\section{Assessment of inflammatory mediator (IL-6 and IL-8) release} The release of inflammatory mediators interleukin 6 and 8 (IL-6 and IL-8) into the exposure media were measured using sandwich enzyme-linked immunosorbent assays (ELISA). The assays were performed using DuoSet ${ }^{\natural}$ antibody kits (R\&D systems, USA) following the manufacturer's protocol. The potential nanoparticle interference was determined by adding NPs, $0-50 \mu \mathrm{g} /$ $\mathrm{ml}$, into standard solution of IL-6 or IL- 8 before the ELISA was performed. No significant interference $(p>0.001, n=3)$ was observed between the normal standard and the NP-addition standard suggesting that the NPs did not interfere with the ELISA assay. The data were collected by reading optical absorption at wavelength of $450 \mathrm{~nm}$ using a Thermomax microplate reader (MTX Lab Systems, USA). Six replicate experiments were carried out using cells isolated from six different donors.

\section{Reactive oxygen species (ROS)}

Intracellular oxidative stress in cells was detected by imaging the fluorescence probes resulting from oxidation of dihydroethidium (DHE) or 2', 7'-dichlorodihydrofluorescein diacetate (H2-DCFDA). The H2-DCFDA is a permeable compound which only detects intracellular ROS. DHE is a readily permeable fluorescent dye which can be oxidized by ROS, primarily superoxide, to yield ethidium molecules. Ethidium subsequently binds to DNA, which produces a detectable red fluorescence signal. After the exposure cells were washed twice with warm PBS and incubated with $200 \mu \mathrm{l}$ of $10 \mu \mathrm{M}$ DHE or $5 \mu \mathrm{M}$ H2-DCFDA (both from Invitrogen, UK) in serumfree medium for $20 \mathrm{~min}$. At the end of H2-DCFDA or DHE incubation, cells were washed twice to remove extracellular probe. The cells were imaged using Leica SP2 inverted fluorescent microscopy (Germany) using optical zoom $\times 10$ and $\times 20$. During imaging, the cells were maintained with $5 \% \mathrm{CO}_{2}$ and $95 \% \mathrm{O}_{2}$ in the live cell imaging chamber with heated base setting at $37{ }^{\circ} \mathrm{C}$. The mean fluorescent intensity (MFI) of the $\mathrm{H}_{2}$ DCFDA $($ ex488/em512nm) and DHE (ex535/610 nm) in the images was quantified using ImageJ (FIJI). Experiments were performed in triplicate.

\section{Glutathione assay (GSH)}

Cellular antioxidant glutathione (GSH) was analysed using GSH/GSSH ratio assay kit (Calbiochem, Merckbioscience,
UK) following the manufacturer's protocol. Briefly, after the exposure cells were collected by centrifugation at 2000xg for $10 \mathrm{~min}$ at $4{ }^{\circ} \mathrm{C}$. The cell pellet was sonicated in 1-2 ml of cold PBS buffer for $10 \mathrm{~min}$ and the cell debris was removed by centrifugation at $10,000 \mathrm{xg}$ for $15 \mathrm{~min}$ at $4{ }^{\circ} \mathrm{C}$. The supernatant was collected and deprotonated by adding $10 \%$ metaphosphoric acid and centrifuged at $5000 \mathrm{xg}$ for $10 \mathrm{~min}$ at $4{ }^{\circ} \mathrm{C}$. The supernatant was stored at $-20{ }^{\circ} \mathrm{C}$ until the assay was carried out. The optical absorbance at a wavelength of $450 \mathrm{~nm}$ was determined using a Thermomax microplate reader (MTX Lab Systems, USA). Experiments were carried out in triplicate.

\section{Monitoring mitochondrial pathology using MitoTracker ${ }^{\circledast}$ Green FM}

MitoTracker ${ }^{\circ}$ Red FM is a readily permeable fluorescent dye exhibiting potential-dependent accumulation in active mitochondria within live cells. The loss of mitochondrial membrane potential inside the cells will cause a reduction in the accumulation of the dye. Following NP exposure, the cells were washed twice with PBS before they were incubated with $50 \mathrm{nM}$ of MitoTracker ${ }^{\circ}$ Red FM in RPMI medium for $45 \mathrm{~min}$ at $37{ }^{\circ} \mathrm{C}$ in $5 \%$ $\mathrm{CO}_{2}$. At the end of the incubation, cells were washed twice with PBS to remove the excess probe before the fluorescent intensity of each well was measured using the Multi-detection multiplate reader SynergyTM HT (BioTek ${ }^{\circ}$ Instrument Inc., USA) at an excitation and emission wavelength of 490 and $516 \mathrm{~nm}$, respectively. Three and six replicate experiments were carried out on TT1 cells and AT2/MAC respectively.

\section{Monitoring lysosomal integrity using Lysotracker Red DND-99}

The readily permeable probe, Lysotracker Red DND-99 (Invitrogen, UK), was used to monitor number of intact lysosomes following 4 and 24-h treatment with NPs. Following NP exposure, the cells were rinsed with PBS twice and incubated with RPMI culture medium containing $50 \mathrm{nM}$ of the Lysotracker Red DND-99 probe, for $40 \mathrm{~min}$. At the end of the incubation period, cells were washed twice with PBS to remove the excess probe and fluorescence intensity in each well was quantified using the Multi-detection multiplate reader SynergyTM HT (BioTek ${ }^{\circ}$ Instrument Inc., USA) at excitation and emission wavelength of 577 and $590 \mathrm{~nm}$, respectively. The experiments were performed in triplicate.

\section{Confocal fluorescence microscopy}

For fluorescence microscopy, following NP exposure the cells were fixed with $3.5 \%$ paraformaldehyde, and permeabilised with $0.1 \%$ triton X-100 for $20 \mathrm{~min}$. At least 20 cells were surveyed per one slide $(n=10)$ and three separate experiments were performed (total $n=30$ ). 
Cells were next washed twice with PBS and blocked with $1 \%$ BSA in PBS for 30 min before staining with Alexa fluor $^{\circ} 555$ anti-cytochrome C (1:100 in blocking buffer; Invitrogen, UK), for $1 \mathrm{~h}$. Cells were washed with PBS and stained with the mouse monoclonal primary antibody to mitochondria (Abcam, UK; dilution 1:100 in blocking solution) for $1 \mathrm{~h}$. The cells were washed and stained with Alexa fluor488 anti-mouse IgG secondary antibody (1:100 in blocking buffer; BD Pharmingen, UK). Cells were rinsed well and mounted onto the slides with ProLong ${ }^{\oplus}$ Gold (Invitrogen) before they were visualised using Leica SP5 inverted confocal microscopy (Leica, Germany). Not less than 15 cells were observed in each slide and three slides were prepared for each sample, $n=45$ cells (total observed).

\section{Transmission electron microscopy (TEM)}

Following NP exposure, the cells were rinsed and fixed with $2.5 \%$ glutaraldehyde for $2 \mathrm{~h}$ and then rinsed with sodium cacodylate buffer. The samples were post-fixed in $1 \%$ osmium tetroxide for $1 \mathrm{~h}$ and dehydrated (with $25,50,75 \%$ and dry ethanol) before embedding into resin (Araldite ${ }^{\circ}$ ) and microtomed into ultra-thin section (50-120 nm thick). The obtained sections were stained with $2 \%$ uranyl acetate $(w / v$ in ethanol) and lead citrate before viewing under TEM. Samples were processed for observation using TEM (Hitachi H7000 Nissei Sangyo Co., Ltd, Japan).

\section{TEM particle uptake analysis}

This technique was adopted from our previous study [63]. Three embedded samples obtained from three replicate experiments were prepared, and three sections were cut from each embedded sample for viewing (total 9 viewing sections (grids) per one sample). At least 10 cells were randomly selected from one section for observation (total viewing 90 cells per sample). The percent cell uptake which was calculated from the number of particle-internalised cells against the number of total cells in each embedded sample (30 cells/3 viewing sections), and the percent cell uptake was calculated from 3 replicate experiments $(n=3)$ to achieve the total number of 90 observed cells (from 9 viewing sections).

\section{Observation of mitochondrial structure}

Three embedded samples obtained from three deprecated experiments were prepared, and two sections were cut from each embedded sample for viewing (total 6 viewing sections (grids) per one sample). At least 10 cells were randomly selected from one viewing section, and their mitochondrial structures were observed (total viewing $n=60$ cells per sample).

\section{Scanning electron microscopy (SEM)}

For SEM analysis, cells were seeded onto coverslips for TT1 cells and MAC, and on collagen coated coverslips for AT2 cells. After NP exposure, the cells were processed using glutaraldehyde fixative $(2.5 \%)$ for $2 \mathrm{~h}$ and osmocated for $1 \mathrm{~h}$. The coverslips were then critical point dried by immersion in hexamethydisilazane (HMD) before attaching to the stubs. The specimens ( $n=60 ; 20$ cells were randomly recruited from three separate experiments) were coated with gold before being visualised under Hitachi S4000 SEM microscopy (Nissei Sanyo, Japan).

\section{Statistical analysis}

The data are presented as mean \pm standard deviation (SD) where three and six replicate experiments were performed. The data were analysed by one-way and two-way analysis of variance (ANOVA) with Post-hoc analysis (Bonferroni) using GraphPad Prism 5 software. Differences were considered significant at $p<0.05,{ }^{* * *} p<0.001$ and ${ }^{* * * *} p<0.0001$. The number of experiments have been described for each assay above and as appropriate.

\section{Additional file}

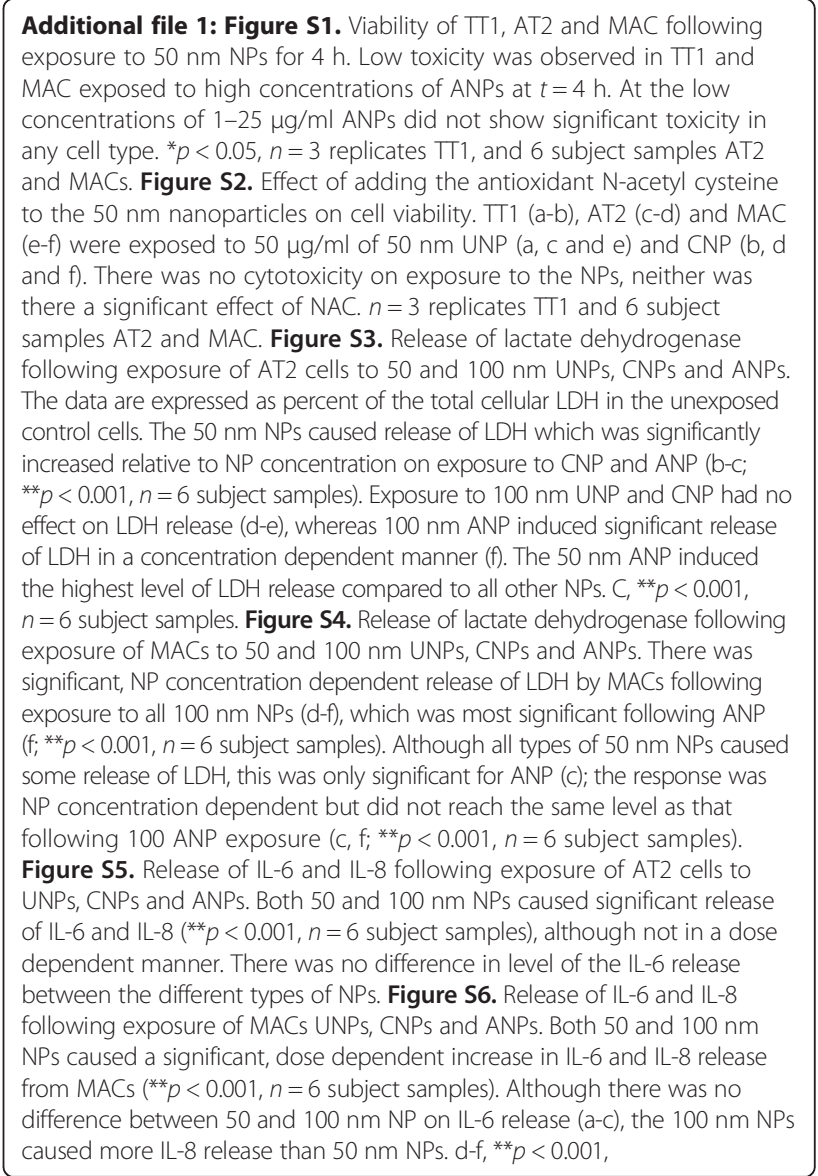


$n=6$ subject samples. Figure S7. Induction of reactive oxygen species in TT1 and AT2 cells exposed to UNP, CNP and ANP. The data are shown as images (a-r) and quantitatively as bar charts (s-u). ANP initiated ROS production following $4 \mathrm{~h}$ exposure at concentrations of $25 \mu \mathrm{g} / \mathrm{ml}$ and above (b-d; s). ROS activated by $50 \mathrm{\mu g} / \mathrm{ml}$ of ANPs remained significantly high at $24 \mathrm{~h}(\mathrm{f}, \mathrm{t}), \mathrm{CNP}$ took up to $24 \mathrm{~h}$ to initiate ROS production in TT1 cells $(\mathrm{g}$; $\mathrm{t})$, although this was lower than that for ANP. UNPs initiated only a small, but significant degree of TT1 cell ROS production at $24 \mathrm{~h}(\mathrm{~h}$; $\mathrm{t}$ ). All types of NPs caused increased AT2 cell ROS production in a concentration dependent manner (i-r; u). The fluorescence intensity of ROS are quantified and presented as mean fluorescence intensity $(\mathrm{MFI} \pm \mathrm{SD})$ as shown in $\mathrm{s}-\mathrm{u}$. ${ }^{*} p<0.001,{ }^{* *} p<$ $0.0001, n=3$ replicate experiments for $\Pi 1$ cells and 3 subject samples for AT2 cells.

\section{Abbreviations}

AT1: Human alveolar epithelial type 1 cells; TT1: Immortalised human alveolar type 1 cells; AT2: Primary human alveolar epithelial type 2 cells; ANP: Amine-modifed polystyrene latex nanoparticles; CNP: Carboxyl-modified polystyrene latex nanoparticles; DHE: Dihydroethidium; GSH: Glutathione; H2-DCFDA: 2',7'-dichlorodihydrofluorescein diacetate; LDH: Lactate dehydrogenase assay; MAC: Primary human alveolar macrophages; MTT: 3-(4,5-Dimethylthiazol-2-yl)-2,5-diphenyltetrazolium bromide; NAC: N-acetyl cysteine; NP: Nanoparticles; PBS: Phosphate buffered saline; ROS: Reactive oxygen species; SEM: Scanning electron microscopy; SD: Standard deviation; TEM: Transmission electron microscopy; UNP: Unmodified polystyrene latex nanoparticles.

\section{Competing interests}

This research was supported by Medical Research Council of United Kingdom (MRC), grant number G0700926, and the NIHR Respiratory Disease Bio-medical Research Unit at the Royal Brompton and Harefield NHS Foundation Trust and Imperial College London. The authors report no competing financial interests related to this manuscript.

\section{Authors' contributions}

The author responsibilities were as follows PR and TDT designed the experiments; PR performed all experiments and wrote the manuscript with help from TDT who critically appraised and approved all versions of the manuscript.

\section{Acknowledgements}

We thank Dr Andrew V. Rogers for proficient assistance with electron microscopy.

\section{Received: 24 September 2014 Revised: 22 February 2015 \\ Accepted: 26 May 2015}

Published online: 02 July 2015

\section{References}

1. Dames P, Gleich B, Flemmer A, Hajek K, Seidl N, Wiekhorst F. Targeted delivery of magnetic aerosol droplets to the lung. Nat Nanotechnol. 2007;2(8):495-9.

2. Rytting E, Nguyen J, Wang X, Kissel T. Biodegradable polymeric nanocarriers for pulmonary drug delivery. Expert Opin Drug Deliv. 2008;5(6):629-39.

3. Kurmi BD, Kayat J, Gajbhiye V, Tekade RK, Jain NK. Micro- and nanocarrier-mediated lung targeting. Expert Opin Drug Deliv. 2010;7(7):781-94.

4. Jensen DK, Jensen LB, Koocheki S, Bengtson L, Cun D, Nielsen HM, et al. Design of an inhalable dry powder formulation of DOTAP-modified PLGA nanoparticles loaded with siRNA. J Control Release. 2012;157(1):141-8.

5. Zhang L, Gu FX, Chan JM, Wang AZ, Langer RS, Farokhzad OC. Nanoparticles in medicine: therapeutic applications and developments. Clin Pharmacol Ther. 2008;83(5):761-9.

6. Petros RA, DeSimone JM. Strategies in the design of nanoparticles for therapeutic applications. Nat Rev Drug Discov. 2010;9(8):615-27.

7. Thorley AJ, Tetley TD. New perspectives in nanomedicine. Pharmacol Ther. 2013;140(2):176-85.

8. Sheridan C. Proof of concept for next-generation nanoparticle drugs in humans. Nat Biotechnol. 2012;30(6):471-3.
9. Mikhaylova M, Stasinopoulos I, Kato Y, Artemov D, Bhujwalla ZM. Imaging of cationic multifunctional liposome-mediated delivery of COX-2 siRNA. Cancer Gene Ther. 2009;16(3):217-26.

10. Uchida S, Itaka K, Chen Q, Osada K, Ishii T, Shibata MA, et al. PEGylated polyplex with optimized PEG shielding enhances gene introduction in lungs by minimizing inflammatory responses. Mol Ther. 2012;20(6):1196-203.

11. Polach KJ, Matar M, Rice J, Slobodkin G, Sparks J, Congo R, et al. Delivery of siRNA to the mouse lung via a functionalized lipopolyamine. Mol Ther 2012;20(1):91-100.

12. Peer D, Karp JM, Hong S, Farokhzad OC, Margalit R, Langer R. Nanocarriers as an emerging platform for cancer therapy. Nat Nanotechnol. 2007;2(12):751-60.

13. McLachlan G, Davidson H, Holder E, Davies LA, Pringle IA, Sumner-Jones SG, et al. Pre-clinical evaluation of three non-viral gene transfer agents for cystic fibrosis after aerosol delivery to the ovine lung. Gene Ther. 2011;18(10):996-1005.

14. Zhang J, Wu L, Chan HK, Watanabe W. Formation, characterization, and fate of inhaled drug nanoparticles. Adv Drug Deliv Rev. 2011;63(6):441-55.

15. Jaafar-Maalej C, Elaissari A, Fessi H. Lipid-based carriers: manufacturing and applications for pulmonary route. Expert Opin Drug Deliv. 2012;9(9):1111-117.

16. Thorley AJ, Ruenraroengsak P, Potter TE, Tetley TD. Critical Determinants of Uptake and Translocation of Nanoparticles by the Human Pulmonary Alveolar Epithelium. ACS Nano. 2014;8(11):11778-89.

17. Xia T, Kovochich M, Brant J, Hotze M, Sempf J, Oberley T, et al. Comparison of the abilities of ambient and manufactured nanoparticles to induce cellular toxicity according to an oxidative stress paradigm. Nano Lett. 2006;6(8):1794-807.

18. Li N, Xia T, Nel AE, Nel AE. The role of oxidative stress in ambient particulate matter-induced lung diseases and its implications in the toxicity of engineered nanoparticles. Free Radic Biol Med. 2008;44(9):1689-99.

19. Barkauskas CE, Cronce MJ, Rackley CR, Bowie EJ, Keene DR, Stripp BR, et al. Type 2 alveolar cells are stem cells in adult lung. J Clin Invest. 2013;123(7):3025-36.

20. Tetley TD. Inflammatory cells and chronic obstructive pulmonary disease. Curr Drug Targets Inflamm Allergy. 2005;4(6):607-18.

21. Thorley AJ, Grandolfo D, Lim E, Goldstraw P, Young A, Tetley TD. Innate immune responses to bacterial ligands in the peripheral human lung role of alveolar epithelial TLR expression and signalling. PLoS One. 2011;6(7), e21827.

22. Basha G, Novobrantseva TI, Rosin N, Tam YY, Hafez IM, Wong MK, et al. Influence of cationic lipid composition on gene silencing properties of lipid nanoparticle formulations of siRNA in antigen-presenting cells. Mol Ther. 2011;19(12):2186-200.

23. Marano F, Hussain S, Rodrigues-Lima F, Baeza-Squiban A, Boland S. Nanoparticles: molecular targets and cell signalling. Arch Toxicol. 2011;85(7):733-41.

24. Minocha S, Mumper RJ. Effect of Carbon Coating on the Physico-chemical Properties and Toxicity of Copper and Nickel Nanoparticles. Small. 2012;8(21):3289-99.

25. Panas A, Marquardt C, Nalcaci O, Bockhorn H, Baumann W, Paur H R, Mulhopt S, Diabate S, Weiss C: Screening of different metal oxide nanoparticles reveals selective toxicity and inflammatory potential of silica nanoparticles in lung epithelial cells and macrophages. Nanotoxicology. 2012;7(3):259-73.

26. Foster KA, Oster CG, Mayer MM, Avery ML, Audus KL. Characterization of the A549 cell line as a type II pulmonary epithelial cell model for drug metabolism. Exp Cell Res. 1998;243(2):359-66.

27. Grainger Cl, Greenwell LL, Lockley DJ, Martin GP, Forbes B. Culture of Calu-3 cells at the air interface provides a representative model of the airway epithelial barrier. Pharm Res. 2006;23(7):1482-90.

28. Raju SV, Wang G. Suppression of adenosine-activated chloride transport by ethanol in airway epithelia. PLoS One. 2012;7(3), e32112.

29. Kemp SJ, Thorley AJ, Gorelik J, Seckl MJ, O'Hare MJ, Arcaro A, et al. Immortalization of human alveolar epithelial cells to investigate nanoparticle uptake. Am J Respir Cell Mol Biol. 2008;39(5):591-7.

30. Witherden IR, Vanden Bon EJ, Goldstraw P, Ratcliffe C, Pastorino U, Tetley TD. Primary human alveolar type II epithelial cell chemokine release: effects of cigarette smoke and neutrophil elastase. Am J Respir Cell Mol Biol. 2004;30(4):500-9.

31. Ruenraroengsak P, Novak P, Berhanu D, Thorley AJ, Valsami-Jones E, Gorelik J, et al. Respiratory epithelial cytotoxicity and membrane damage (holes) caused by amine-modified nanoparticles. Nanotoxicology. 2012;6(1):94-108.

32. Nel AE, Madler L, Velegol D, Xia T, Hoek EM, Somasundaran P, et al. Understanding biophysicochemical interactions at the nano-bio interface. Nat Mater. 2009;8(7):543-57. 
33. Lundqvist M, Stigler J, Elia G, Lynch I, Cedervall T, Dawson KA. Nanoparticle size and surface properties determine the protein corona with possible implications for biological impacts. Proc Natl Acad Sci U S A. 2008;105(38):14265-70

34. Brown DM, Wilson MR, MacNee W, Stone V, Donaldson K. Size-dependent proinflammatory effects of ultrafine polystyrene particles: a role for surface area and oxidative stress in the enhanced activity of ultrafines. Toxicol Appl Pharmacol. 2001;175(3):191-9.

35. Prietl B, Meindl C, Roblegg E, Pieber TR, Lanzer G, Frohlich E. Nano-sized and micro-sized polystyrene particles affect phagocyte function. Cell Biol Toxicol. 2014;30(1):1-16.

36. Pack DW, Hoffman AS, Pun S, Stayton PS. Design and development of polymers for gene delivery. Nat Rev Drug Discov. 2005;4(7):581-593.37.

37. Novak P, Shevchuk A, Ruenraroengsak P, Miragoli M, Thorley AJ, Klenerman $D$, et al. Imaging single nanoparticle interactions with human lung cells using fast ion conductance microscopy. Nano Lett. 2014;14(3):1202-7.

38. Winzen S, Schoettler S, Baier G, Rosenauer C, Mailaender V, Landfester K, et al. Complementary analysis of the hard and soft protein corona: sample preparation critically effects corona composition. Nanoscale. 2015;7(7):2992-3001.

39. Marchetti M, Shaffer MS, Zambianchi M, Chen S, Superti F, Schwander S, et al. Adsorption of surfactant protein $D$ from human respiratory secretions by carbon nanotubes and polystyrene nanoparticles depends on nanomaterial surface modification and size. Philos Trans R Soc Lond B Biol Sci. 2015;370:1661.

40. Herzog F, Loza K, Balog S, Clift MJ, Epple M, Gehr P, et al. Mimicking exposures to acute and lifetime concentrations of inhaled silver nanoparticles by two different in vitro approaches. Beilstein J Nanotechnol. 2014;5:1357-70.

41. Kim JA, Aberg C, de CG, Malumbres M, Salvati A, Dawson KA. Low dose of amino-modified nanoparticles induces cell cycle arrest. ACS Nano. 2013;7(9):7483-94.

42. Xia T, Kovochich M, Liong M, Zink Jl, Nel AE. Cationic polystyrene nanosphere toxicity depends on cell-specific endocytic and mitochondrial injury pathways. ACS Nano. 2008;2(1):85-96.

43. Bhattacharjee $S$, de Haan LH, Evers NM, Jiang X, Marcelis AT, Zuilhof H, et al. Role of surface charge and oxidative stress in cytotoxicity of organic monolayer-coated silicon nanoparticles towards macrophage NR8383 cells. Part Fibre Toxicol. 2010;7:25.

44. Nagy A, Steinbruck A, Gao J, Doggett N, Hollingsworth JA, lyer R. Comprehensive analysis of the effects of CdSe quantum dot size, surface charge, and functionalization on primary human lung cells. ACS Nano. 2012;6(6):4748-62

45. Sheth DS, Tajuddin NF, Druse MJ. Antioxidant neuroprotection against ethanol-induced apoptosis in HN2-5 cells. Brain Res. 2009;1285:14-21.

46. Aggarwal A, Misro MM, Maheshwari A, Sehgal N. Differential modulation of apoptotic gene expression by $\mathrm{N}$-acetyl-L-cysteine in Leydig cells stimulated persistently with hCG in vivo. Mol Cell Endocrinol. 2012;348(1):155-64.

47. Green DR, Kroemer G. The pathophysiology of mitochondrial cell death. Science. 2004;305(5684):626-9.

48. Yacobi NR, DeMaio L, Xie J, Hamm-Alvarez SF, Borok Z, Kim KJ, et al. Polystyrene nanoparticle trafficking across alveolar epithelium. Nanomedicine. 2008;4(2):139-45.

49. Yacobi NR, Malmstadt N, Fazlollahi F, DeMaio L, Marchelletta R, Hamm-Alvarez SF, et al. Mechanisms of alveolar epithelial translocation of a defined population of nanoparticles. Am J Respir Cell Mol Biol. 2010;42(5):604-14.

50. Lin J, Alexander-Katz A. Cell membranes open "doors" for cationic nanoparticles/ biomolecules: insights into uptake kinetics. ACS Nano. 2013;7(12):10799-808.

51. Chen J, Hessler JA, Putchakayala K, Panama BK, Khan DP, Hong S, et al. Cationic nanoparticles induce nanoscale disruption in living cell plasma membranes. J Phys Chem B. 2009;113(32):11179-85.

52. Lin JQ, Zheng YG, Zhang HW, Chen Z. A simulation study on nanoscale holes generated by gold nanoparticles on negative lipid bilayers. Langmuir. 2011;27(13):8323-32.

53. Varkouhi AK, Scholte M, Storm G, Haisma HJ. Endosomal escape pathways for delivery of biologicals. J Control Release. 2011;151(3):220-8.

54. Shete HK, Prabhu RH, Patravale VB. Endosomal escape: a bottleneck in intracellular delivery. J Nanosci Nanotechnol. 2014;14(1):460-74.

55. Mu Q, Yang L, Davis JC, Vankayala R, Hwang KC, Zhao J, et al. Biocompatibility of polymer grafted core/shell iron/carbon nanoparticles. Biomaterials. 2010;31(19):5083-90.
56. Oh WK, Kim S, Choi M, Kim C, Jeong YS, Cho BR, et al. Cellular uptake, cytotoxicity, and innate immune response of silica-titania hollow nanoparticles based on size and surface functionality. ACS Nano. 2010;4(9):5301-13.

57. Soenen SJ, Illyes E, Vercauteren D, Braeckmans K, Majer Z, De Smedt SC, et al. The role of nanoparticle concentration-dependent induction of cellular stress in the internalization of non-toxic cationic magnetoliposomes. Biomaterials. 2009;30(36):6803-13.

58. Baoum A, Dhillon N, Buch S, Berkland C. Cationic surface modification of PLG nanoparticles offers sustained gene delivery to pulmonary epithelial cells. J Pharm Sci. 2010;99(5):2413-22.

59. Sparks J, Slobodkin G, Matar M, Congo R, Ulkoski D, Rea-Ramsey A, et al. Versatile cationic lipids for siRNA delivery. J Control Release. 2012;158(2):269-76.

60. Frohlich E, Meindl C, Roblegg E, Ebner B, Absenger M, Pieber TR. Action of polystyrene nanoparticles of different sizes on lysosomal function and integrity. Part Fibre Toxicol. 2012;9:26.

61. Thorley AJ, Ford PA, Giembycz MA, Goldstraw P, Young A, Tetley TD. Differential regulation of cytokine release and leukocyte migration by lipopolysaccharide-stimulated primary human lung alveolar type II epithelial cells and macrophages. J Immunol. 2007;178(1):463-73.

62. Witherden IR, Tetley TD. Isolation and Culture of Human Alveolar Type II Pneumocytes. Methods Mol Med. 2001;56:137-46.

63. Miragoli M, Novak P, Ruenraroengsak P, Shevchuk Al, Korchev YE, Lab MJ, et al. Functional interaction between charged nanoparticles and cardiac tissue: a new paradigm for cardiac arrhythmia? Nanomedicine (Lond). 2013;8(5):725-37.

\section{Submit your next manuscript to BioMed Central and take full advantage of:}

- Convenient online submission

- Thorough peer review

- No space constraints or color figure charges

- Immediate publication on acceptance

- Inclusion in PubMed, CAS, Scopus and Google Scholar

- Research which is freely available for redistribution 